University of Louisville

ThinkIR: The University of Louisville's Institutional Repository

Electronic Theses and Dissertations

1944

\title{
A study of the failures in the 6A grades of Louisville, Kentucky, for the year 1941-1942.
}

Lena Ruth Towles 1905-1966

University of Louisville

Follow this and additional works at: https://ir.library.louisville.edu/etd

Part of the Education Commons

\section{Recommended Citation}

Towles, Lena Ruth 1905-1966, "A study of the failures in the 6A grades of Louisville, Kentucky, for the year 1941-1942." (1944). Electronic Theses and Dissertations. Paper 2176.

https://doi.org/10.18297/etd/2176

This Master's Thesis is brought to you for free and open access by ThinkIR: The University of Louisville's Institutional Repository. It has been accepted for inclusion in Electronic Theses and Dissertations by an authorized administrator of ThinkIR: The University of Louisville's Institutional Repository. This title appears here courtesy of the author, who has retained all other copyrights. For more information, please contact thinkir@louisville.edu. 


\title{
UNIVERSITY OF LOUISVILIE
}

\author{
A Study of the Failures \\ in the $6 \mathrm{~A}$ Grades of Louisville, \\ Kentucky, for the Year 1941-42
}

A Thesis

Submitted to the Faculty

Of the Graduate School of the University of Louisville

In Partial Fulfillment of the

Requirements for the Degree

of Master of Arts

Department of Education

by

Iena Ruth Towles

Year

1944 
This PDF document is a scanned copy of a paper manuscript housed in the University of Louisville (UofL) Libraries. The quality of this reproduction is greatly dependent upon the condition of the original paper copy. Indistinct print and poor quality illustrations are a direct reflection of the quality of materials that are available for scanning. The UofL Libraries greatly appreciates any better copies that can be made available for replacement scans. 
NAME OF STUDENT: Lena Ruth Towles

TITLE OF THESIS: A Study of the Failures in the 6A Grades of Louisville, Kentucky, for the Year 1941-42

APPROVED BY READING CORAITTEE CONPOSED OF THE FOLLOWING MEMBERS:

Hilda Threlkeld

Ernest C. Hassold

NAME OF DIRECTOR: J. J. Oppenheimer

DATE: Qet, 14,1944 
A Study of the Failures

in the 6A Grades of Louisville,

Kentucky, for the Year 1941-42 
TABLE OF CONTENTS

CHAPTER

I. THE PROBLEM AND MATERIALS AND METHODS USED IN SOLVING IT

The problem

Statement of the problem 2

Value of the study 3

Materials and methods used in the study 3

Consideration of available statistics 3

$\begin{array}{ll}\text { Use of questionnaire } & 6\end{array}$

II. REVIEN OF THE IITERATURE

The extent of failure 9

Causes of failure 15

Prevention of failure $\quad 26$

The slow learning and mentally retarded child $\quad 40$

The sex of the child as a factor in failure 50

Absence of such studies in Louisville 62

III. FINDINGS ON THE INCIDENCE OF FAILURE

IN LOUISVILIE

Comparison for the last five years 66

Comparison for February and June semesters of $1941-1942$ 
IV. STATUS OF FAILURES USED IN THIS STUDY 72

Ages of failures 72

Mental ages and intelligence quotients of failures

Bureau of Research information $\quad 79$

Number of boys and girls 80

V. CAUSES OF FAILURE 86

Questionnaire results $\quad 86$

Attendance percentages $\quad 91$

Achievement test results 105

VI. HEIP GIVEN BEFORE FAILURE 114

Questionnaire results $\quad 115$

Bureau of Research findings 116

Information on available help in

Louisville school system 118

VII. CONSEQUENCES OF FAILURE 123

Questionnaire results $\quad 123$

$\begin{array}{ll}\text { Teachers' marks } & 126\end{array}$

$\begin{array}{ll}\text { Attendance percentages } & 128\end{array}$

VIII. SUMMARY AND CONCLUSIONS 133

$\begin{array}{ll}\text { Summary } & 133\end{array}$

$\begin{array}{ll}\text { Conclusions } & 139\end{array}$

$\begin{array}{ll}\text { BIBLIOGRAPHY } & 144\end{array}$ 


\section{IIST OF TABLES}

TABIE

I. Causes of Failure Given by School Ohildren Questioned by Borgeson

II. Opinions of Principals as to the Value of Grade Repetition

III. Means of Reducing Failure as Iisted by 555 Superintendents

IV. Baltimore Plan for Movement Through the Grades

V. Rate of Progress of $6 \mathrm{~A}$ and $6 \mathrm{~B}$ Pupils, Louisville Public Schools, 194\& - 1943

VI. Percentage Distribution of the Incidence of Retardation by Half Grades

VII. Promotion Percentages by Grades of the Elementary Schools and the First Two Years of Junior High Schools of Louisville, Kentucky for the Five Year Period from 1938-39 Through 1941-42

VIII. Average Failure Percentages of the First Eight Grades of the Louisville Public School the Five Year Period from 1938-39 Through 1941-42

IX. Chronological Age Spread at Date of Failure for 66 Children who Were Failures in the 6A Grades of the Louisville Public Schools, Year 1941-42 
TABLE

X. Spread of Intelligence Quotients of Failures from the 6A Grades of the Louisville Public Schools for the Year 1941-42

XI. Types of Tests Given Failures from the 6A Grades for the Year 1941-42 Who Were Given Special Tests During Their Membership in the Louisville Public Schools

XII. Promotion Percentages for Children of the 6A Grades of the Louisville Public Schools for the Five School Years 1937-38 Through 1941-42 82

XIII. Numbers of Pupils who Were Subject Failures for June 1942, Showing Percentages of Boys and Girls Separately 83

XIV. Results from the Questionnaire Sent to the Teachers of 6A Failures for the Year 1941-42 87 XV. Reasons Ascribed by Their Teachers for Failures of Children Not Promoted in the 6A Grades of Louisville for the Year 1941-42 Arranged According to Number of Checks on the Questionnaires

XVI. Attendance Record Showing Number of $6 \mathrm{~A}$ Failures for the Year 1941-42 Who Had Various Attendance Percentages 
XVII. Standing on Kuhlmann-Anderson Tests of $6 \mathrm{~A}$ Failure for the Year 1941-42 Checked Mentally Incapable on the Questionnaires Sent in by Their Teachers

XVIII. Chronological Ages of 6A Failures for the Year 1941-42 Who Were Marked on Questionnaires as Failures Because of Immaturity

XIX. Marks Assigned by Teachers to 62 of the Children Who Were Failures in the 6A Grades for the Year 1941-42

XX. A Study of Twelve of the 6A Failures for the Year 1941-42 and Their Standing Within Their Own Class Groups According to Scores Made on the Progressive Achievement Tests With Percentages Showing the Ratio of Children in Each Class Who Made Similar or Lower Scores on These Tests

XXI. Comparison of Teachers' Grades and Achievement Test Results for Five of the 6A Failures for the Year 1941-42 Whose Achievement Did Not Seem as Low as Teachers' Grades Would Indicate

XXII. Teachers' Opinions as to Consequences of Failures of $6 \mathrm{~A}$ Children for Year 1941-42 
TABLE

PAGE

XXIII. Differences in Teachers' Grades Made by 6A

Failures for Year 1941-42 in Which They

Failed and the Following semester

XXIV. Increase or Decrease in Percentages of Attendance Shown by 6A Failures for Year 1941-42 in the Semester After the one in Which They Failed 


\section{IIST OF GRAPHS}

EIGURE

PAGE

I Age Groups at Date of Failure for Children Who Were Failures in the 6A Grades of the Louisville Public Schools for the Year 1941-42

2 Grouping of Intelligence Quotients as Shown by Kuhlmann-Anderson Tests for Failures from the 6A Grades of the Louisville Public Schools for the Year $1941-42$ 
CHAPTHR I

THE PROBLEM AND MATERIALS AND METHODS USED IN SOLVING IT 


\section{CHAPTER I}

THE PROBLFM AND MATERIALS AND METHODS USED IN SOLVING IT

Numerous studies have been made in recent years of the incidence, the causes and the results of failure in the elementary schools. These studies have been made for the purpose of furnishing scientific evidence to substantiate the belief, held by many, that too lazge a number of young children have been asked to repeat grades at considerable personal loss. These studies have sprung from an increasingly popular philosophy that each child should be treated as an individual, and that careful consideration should be given every part of his school life.

\section{THE PROBLEM}

Statement of the problem. It was the purpose of this study (1) to present facts as to the total amount of failure in the $6 \mathrm{~A}$ grade of Louisville for the school year 1941-42; (2) to show how the percentage of failure in that grade cornpared with the percentage of failure in other grades in Louisville; (3) to record the chronological ages, mental ages and intelligence quotients of this group; (4) to note the causes of failure as shown on questionnaires answered by the teachers of these children, and as show by statistics from attendance records and achievement test results; (5) to list any measures used to prevent failures which were 
checked on the questionnaires or found by interpreting available records of the Louisville Public Schools; (6) to collect the opinions of teachers relative to the results of the failure of this group of $6 \mathrm{~A}$ children and to find in available attendance and scholarship records for the semester following their failure some exact information to compare with these opinions.

Value of the study. Although hundreds of failure studies have been made in both urban and rural areas of the United States, no study of this sort has been made in Louisville. By making an intensive examination of the children failing in one grade of the Louisville public schools facts were found and conclusions drawn which should have more meaning to the teachers of this area than those gained from other research in the same field. The statistics used in this investigation are those available to all teachers in this city.

II. MATERIALS AND METHODS USED IN THE STUDY

Consideration of available statistics. Promotion sheets are printed forms issued by the superintendent's office to all Louisville elementary schools. They are filled out in duplicate. One copy remains at the school and one is filed in the central office. These sheets are 
completed at each regular promotion period which in Louisville occurs semi-annually. Children are promoted in late January and again in June.

The promotion sheets for January and June of the school year 1941-42 were consulted first in the investigation here reported. From the sheets was learned the number of $6 \mathrm{~A}$ children failing for that year, and the names of the schools and of the teachers in whose rooms these failures took place. Other valuable information to be gained from $t$ these records were the marks of the children for the term in which they failed and their attendance records for that semester. The marks were averages in each subject studied in the 6A. The chronological age at the time of promotion also appeared.

Later it was considered advisable to get similar information from the promotion sheets for the second semester the child spent in $6 \mathrm{~A}$, the term in which he repeated the grade. This meant consulting the sheets for June 1942 for the February 1942 failures, and the February 1943 sheets for the June 1942 group. Where these children had left school or left the city there was, of course, no complete record. Two types of material were consulted in the offices of the Bureau of Research of the Louisville public schools. These were regular test record files and individual test 
records and case studies.

All $6 \mathrm{~A}$ classes of the Louisville schools are given standard tests of intelligence and achievement. These are usually given during the first month of entrance to the grade. They are given by the classroom teacher or the principal of the school. Recently the Kuhlmann-Anderson Intelligence Tests have been used and the Progressive Achievement Tests.

The results of these tests are recorded in triplicate. One copy is kept in the elementary school giving the test, one is sent to the junior high school which will enroll most of the children in that particular $6 \mathrm{~A}$ and one is put on file in the offices of the Bureau of Research.

This third copy was available for consultation to determine the intelligence and achievement status of the 6 A failures for the year 1941-42. The chronological age at the time of the test was stated on each sheet. Because of the way the information about achievement was recorded it was possible to determine each child's standing in comparison with the other members of the class in the subjects tests as well as in total achievement.

Another interesting type of data to be found at the Bureau of Research was located in the individual case studies which had been made of some of these children. Some- 
times an individual intelligence test had been given. For other children special subject tests yielded the necessary suggestions. Filed with these were case studies made by visiting teachers with the help of classroom teachers and principals.

A few of these pupils had been given some type of special test in their own schools. These were in a special file and yielded information about intelligence and achievement levels at various points in the school progress of the children tested. Occasionally a recommendation for the placing of one of these children appeared on the special test record.

The Superintendent's Annual Report was helpful for general school statistics. This is a small bulletin which contains tables on enrollment, attendance, promotions, school costs and similar subjects. Here were quoted percentages of failure for all the elementary grades for the five school years ending 1941-1942. These tables were consulted to show the standing of the $6 \mathrm{~A}$ in comparison with the other grades. From this report also, numbers of failures in various subjects were compiled.

Use of questionnaire. Certain types of information seemed best ascertained by the use of a questionnaire. This was sent to each teacher whose promotion sheets for January or June of the year 1941-1942 showed 6A failures. There was a sheet of questions to be checked for each child giving 
suspected causes for his failure, the help given him before failure and the attitudes observed in him after failure. A copy of this questionnaire appears on page From these various sources statistics were gathered. After careful study the conclusions stated in another part of this study were drawn. 
CHAPTER II

REVIEW OF THE LITERATURE 


\section{CHAPTER II}

\section{REVIEW OF THE LITERATURE}

Early in the century attention began to be directed to the retardation of large groups of children in the public schools of the United States. When a child is not at the grade level which would be expected for his chronological age he is said to be retarded. Retardation may, of course, be due to either of two causes, late entrance or non-promotion. It is retardation due to non-promotion which is of importance to this study. In this chapter will be reviewed some of the findings most pertinent to this particular research, chosen from a vast amount of literature on the subject of failure and the ensuing retardation of elementary school children.

The extent of failure and retardation in the elementary grades. In 1907 Ayres began some investigations as to the percent of retardation in some of the schools of the United States. He found that the amount varied. His figures showed high of 75 percent in the colored schools of Memphis, Tennessee, and a low of 7 percent in the white schools of Medford, Massachusetts. He found that one-sixth of the children in

Leonard P. Ayres, Laggards in Our Schools, (New York: Charities Publication Committee, 1909), p. 236. 
the entire country had repeated one or more grades.

Later studies show similar facts. Most of them, however, show percents of failure rather than of retardation. These make the picture even clearer because the factor of late entrance is eliminated.

In 1916 an Education Survey of Cleveland-showed, 2

according to Judd, that there were ten thousand failures in the elementary schools of that city and that fourteen hundred were failing for the second time in the same course. In 1924-1925 Heck made a study of twenty-five cities. Eight of these cities showed failure percentages of 10 percent or above. The median was 9.1 percent. These figures did not include provisional failures, children who were demoted during the term or children who left school because of failure. Sumption summarized recent findings on amount of retardation and failure. He felt that confusion of terms made an understanding of this question difficult. He found that the normal age span for a grade was a subject for disagreement among writers in this field. This fact made exact

c. H. Judd, "Measuring the Work of the Public Schools," Education Survey of cleveland, p.17.

3 pp. 356-358.

Arch 0. Heck, Adininistration of Pupil Personnel,

4

M. R. Sumption, "School Progress", pp. 1054-1057. 
accounting of the amount of retardation difficult. In general, however, he seemed to think that studies showed that retardation was still a problem. He mentioned that within the last twenty years techniques for studying this problem have been much improved. He stated that one of these techniques, the age-grade study, still showed overageness in from 20 to 40 percent of the pupil population. He reported that studies seemed to indicate that the percent of retardation was decreasing.

This author continued with information about amounts of failure. He stated that the amount of school failure was difficult to determine because of lack of uniformity. in reporting such facts. He found, however, that statistics seemed to show a variation of from 2 percent in some systems to 80 percent in others. He warned again that this seeming variation may be due to a lack of uniformity in classifying failures as well as a difference in promotional standards. He says that various investigators have found statistics as to differences in amounts of failure between rural and urban areas, between different states, or cities, between different schools within a system, between two grades in the same school. Some of these statistics will be cited later.

Sumption stressed that investigators were almost

Ibid., p: 1056. 
unanimous in reporting more retardation in rural schools than in city systems. This, as before stated, did not necessarily mean a higher rate of non-promotion. In general the smaller schools seemed to have a greater amount of retardation, but that may have been because they were, for a large part, rural schools.

Caswell gave figures on failures within the schools of the same city. In checking on 561 schools in New York City he found a variation of 32 percent in the number of failures, and in nine schools in Santa Monica, California, a variation of 30.7 percent.

Heck quotes some exact statistics to prove that was true of the city of Chicago. One school had 0.4 percent of non-promotion, whereas another has 35.2 percent. In $6 \mathrm{~A}$ Arithmetic fifteen schools passed all the children, and one failed sixty-three percent.

Heck stated further that when standard tests were given there was no correlation between the results of these tests and the teachers' failing marks. In School Number Two, where there were no failures, 54 percent of the children

\footnotetext{
${ }^{6}$ Hollis L. Caswell, Non-Promotion in Elementary Schools, pp. $7-10$.

7 Heck, op.cit., pp. 362-364.
} 
failed on the atandard tests. In school Number 265, where 48 percent of the children failed, only 5 percent failed on the standard tests. of course, there were exceptions. In School Number One a record of no failures was borne out by a similar record on the standard tests.

Judd traced the amount of non-promotion in the grades of Cleveland for three years. He found the greatest amount in the first, fifth, sixth and seventh, with the least in the eighth.

Heck ${ }^{9}$ studied seventeen cities. He found the first grade the highest and the eighth the lowest. Sumption stated that recent studies bear out Heck in these findings. Table Five in Caswell's book showed data for thirty-five cities, twenty-two with semi-annual promotions, and thirteen with annual ones. He reported that there is a decided tendency for the first grade to have the highest rate of non-promotion with IB much higher than IA.

$\mathrm{H}_{e}$ also found differences in the promotion rates of boys and girls. His statistics cover seven cities with an enroliment of about a quarter million. In this group there were more boys than girls. Although the boys' achievement

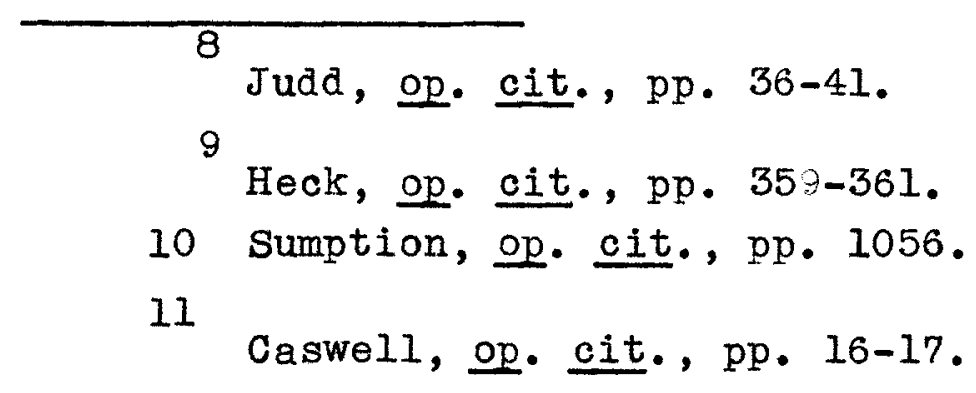


age was eleven years two months and the girls' eleven years and three months, twenty-three percent of the boys failed and only 7.4 percent of the girls. Studies on the reasons for this will be discussed later in this chapter.

To summarize, these studies on the extent of failure and retardation in the elementary grades present the following picture. In the early nineteen hundreds educators became aware of a large overage group in the public schools. Investigations showed large percentages of retardation and failure. The amounts of both are gradually decreasing.

Wide variations in percentages of non-promotion were found between different states, between different cities, between the schools within one system, between the grades, and between the sexes. Studies show that in many cases there is no fair reason for such wide variations.

The cost of failure. Sumption ${ }^{12}$ and Heck ${ }^{13}$ agreed that the old idea that failures meant large financial loss to the schools could no longer be accepted as true. A higher promotion rate usually meant that a greater number of children finished or at least attended high schools and the cost of high schools was far greater than the cost of elementary schools. However, Heck went on to state that the money spent on failures

12 Sumption, op. cit., pp. 1056.
${ }^{13}$ Heck, op. cit., pp. 35\%-354.


was a definite waste or loss. Both men mentioned the loss to the child which will be treated in another part of this chapter.

The causes of failure. Ayres ${ }^{14}$ in 1909 found irregular attendance and physical efects two causes of failure. His study was made much too early, of course, to note the lack of mental ability as an important factor.

In 1929 Briggs studied failures in the schools of Sioux City, Iowa. He sent questionnaires to the teachers of that city. They chose as the three chief causes of failure low mentality, personality and behavior differences, and attendance problems.

In Adams study he records the answers from fortyone teachers to letters he had sent to teachers in his county who had failed more than eight percent of the children in any one class at the end of one particular period. The items and the times mentioned are below. These are the twn items mentioned most often.

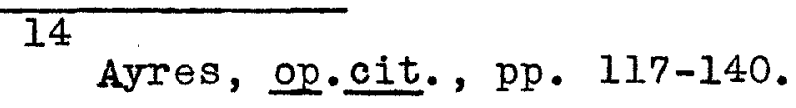

E. E. Briggs, "Studies of Failures in the City Schools", Eighth Yearbook of the Department of Elementary School Principals, pp. $24-244$.

16

W.S.Adams, "Why Teachers Say They Fail Pupils", Educational Administration and Supervision, 18:594-600. (November, 1932$)$. 
1. Work too difficult 47

2. Absence 36

3. Pupils' lack of interest 27

4. Mental deficiencies

(teachers' opinions) 23

5. Excessive moving 22

6. Below teacher's subjective standard 19

7. Reading ability below same 15

8. Pupils careless and

indifferent 14

9. Use of fear of failure
to get better work
12

10. Poor home conditions il

\begin{abstract}
17
Borgeson asked one thousand elementary and secondary school pupils, "What do you consider the cause of failure and poor school work?" The responses of the children showed that the children blamed themselves more than anybody else. The causes given and the number of children ascribing their failure to each one were as follows:
\end{abstract}

F.C.Borgeson, "Causes of Failure and Poor School Work Gien by Pupils", Educational Administration and Supervision, 16:542-48, (October, 1930). 


\section{TABLE I}

CAUSES OF FAILURE GIVEN BY SCHOOL CHILDREN QUESTIONED BY BORGESON

No. of Children

1. Lack of study (do not do homework) 91

2. Assignment not clear 65

3. Disturbance 45

4. Lack of attention 39

5. Laziness, lack of effort 37

6. Poor health habits 36

7. Lack of interest 30

8. Dislike of school work or subject 28

9. Poor study habits 22

10. Teacher's inabilities

11. Irregular attendance 17

12. Lack of responsibility and purpose 11

13. School transfer 11

14. Misbehavior 9

15. Lesson too long or hard 8

16. Out of school interests 6

17. Fear of teacher or group (shyness) 4

18. Inadequate supervision of study 3

19. Cheating 1

20. Lack of ability 1 
The author summarized this material by saying that the pupils assumed the responsibility for their failure in approximately seventy-five percent of the cases. However, he felt that the pupils in taking the blame have shown plainly that the schools have failed to establish proper attitudes in the child toward school, work, teachers, parents, and other adults, and, more important, toward life. Hayes collected data in a small town near Boston with an elementary school population of twenty-seven hundred. The group stood high in the number of children succeeding in college. The children considered were the ones from grades two through five who had repeated grades at some time during their school career. Eighty-three percent of these children had been in the system since the first grade.

Such factors as chronological age st date of entrance to the first grade, mental age at date of entrance, amount of kindergarten training, physical defects and transfer from other schools were considered. Hayes concluded that the mental age at time of entrance to the first grade was the strongest element in the success of school children. of the children who were over six mentally ninety-four percent were promoted regularly, of those only forty-six percent and many of this latter group were found in $C$ divisions. Method, 13:25-28, (October, 1933). 
McGinnis ${ }^{19}$ found teachers giving as the four main reasons for failure, mental retardation, poor home conditions, laziness or indifference, and poor attendance. He discounted all these reasons, saying that teachers' judgment as to mental ability is not always correct. He found that home conditions were rarely investigated so the teacher could be sure they were poor. He put the blame for poor attendance on the school and blamed poor teaching for lazy and indifferent pupils. He felt that the school itself was to blame for failures. More specific causes of non-promotion were mentioned 20

by Brueckiner and Melby since they attempted to give the teacher exact methods of correcting such difficulties wherever that was possible. They mentioned disabilities in specific subjects as well as low intelligence. In listing the pedagogical factors they noted the possibilities of unorganized make-up work after absence, as well as the inadequacy of instructional material and the neglect of the individual in the classroom.

In weighing the emotional factors these authors stressed the need for developing strong positive attitides toward work, and of understanding thoroughly the home life of the individual

\footnotetext{
William G. MCGinnis, "Dodging the Blame for Failures", Journal of Education, 117:209-11, (April 16, 1934). 20

Leo J. Brueckner and Mrnest 0. Melby, Diagnostic and Remedial Teaching, pp.4-11.
} 
child. Under volitional factors they listed lack of confidence and an unwillingness to ask for help as well as a lack of perseverance.

Under social and moral factors they brought out the fact that parents often deliberately counteracted the constructive work of the schoolroom. Theyadvocated socialized recitations as a step towards eliminating anti-social traits.

Heck made four clasifications of causes for failures. Under failure due to the child he listed lack of mental ability and incurable physical defects. Under failure due to the teacher there were four points--poor methods, a lack of understanding or problem cases, false notions about what school standards demand and the personality of the teacher. Failures due to the school came from such causes as too large groups, lack of special groups for pupils of low ability and inadequate preliminary training of pupils. The indifferent attitude of parents is mentioned under failure due to out of school environment.

Lafferty's research found that studies showed little

21 Heck, Op. cit., pp.365-370.

22

H.M. Lafferty, "A Study of the Reasons for Pupil Failure in School", Educational Administration and Supervision, 24:360-67, (May, 1938). 
uniformity in reasons why pupils fail. In summarizing fourteen such studies some of the reasons listed were irregular attendance, poor health and physical defects, poor home conditions, low mentality, lack of interest, poor effort, laziness, poor foundation, teacher's inabilities, lack of home study, dislike of the teacher, social activities, dislike of the subjects. He says that there are four causal agencies to which responsibility ofr pupil failure may be attributed. These are the teacher and the school, the pupil, home conditions, and health factors.

An analysis of the studies reviewed here showed findings similar to Lafferty's. The reasons given for failures varied completely depending upon whether the person asked was pupil, teacher, principal, administrator or educational writer. The philosophy of the investigator also had an important bearing on the interpretation of the results. The organization of such data varied also.

Certain factors tended to appear again and again, however, although they were expressed differently. They were: low mentality, poor attendance, physical, social or mental immaturity, special academic disabilities, and personality traits on the part of the child. Lack of individual work or poor teachings were due to the instructor, and lack of provision for specialized work put the blame on the administrator. 
The value of school failure is still a controversial issue. Conflicting points of view will be reviewed in the following paragraphs.

otto conferred with thirty-eight principals, culling their opinions as to what might be gained from grade-repetition. Twenty-nine percent said there were no desirable values in failure and one principal asserted that failure in the elementary schools was a tragedy. The opinions of the others are listed here.

\section{TABLE II}

OPINIONS OF PRINCIPALS AS TO THE VALUE OF GRADE REPETITION Value No. of Principals Percent

1. Assures the mastery of subject matter 13 34

2. Disciplines lazy child

11 29

3. No values

11 29

4. Adjusts immature child

9

24

5. Helps to retrieve losses due to absence

4

11

6. Gives dull child more time

3

8

7. Maintains the norale or standard

1

3

\section{3}

Henry J. Otto, 焣enentany School Organization and Administration, p. 249 . 
24

In another work this same writer gave the values of failure as expressed by teachers. In order of importance these were: building an academic background for work in the succeeding grades, effecting a better personal and social adjustment of pupils, adjusting ability to assigned work or expected attainment, discipline or the improvement of work habits.

On the other side of the ledger were various opinions as to the harmul effects of failure. Caswell ${ }^{25}$ stated that the effect of non-promotion on personality traits must be judged by the observation of competent students, and case stydies of problem pupils. From use of these sources he was convinced that a bad emotional state developed from failure. He assumed that the harmful characteristics resulting were a fixed attitude of failure, habits of rationalizing, or day dreaming, truancy and disobedience. "In a word, nonpromotion is a type of failure that tends to deaden, disillusion, and defeat the child".

The great educational loss which came to children who were repeatediy failures in the elementary schools was condoled by Heck. They missed, of course, the advantages of

24 Henry J. Otto, Promotion Policies and Practices in Elementary Schools, Educational Monograph Nymber 5, p.2I

25

Caswell, op.cit., pp.68-70.

26

Ibid., p.81.

27

Heck, 으.cit., pp. 354-55. 
diversified courses which the high school offered. He noted as a siritual loss the fact that the child was apt to become a chronic failure in life. Under social loss he put the fact that the overage children required too much of the teacher's time, which often allowed the younger children to waste time. He also suggested that these overage children often passed on bad or vicious habits to the younger ones.

Cook's study dealt with the claim of many educators that high standards of promotion mean greater achievement. $\mathrm{He}_{e}$ chose eighteen school systems in minnesota for his compilation of statistics. The ratio: of overageness was computed for Grade Seven in each school. The list was then arranged according to the amount of overageness and the schools at one extreme were matched with those at the other in regard to size, socio-economic status, and the preparation of teachers. The results of the study showed that the seventh grades with a low ratio of overageness were superior in intelligence and in all achievement except arithmetic fundamentals. Cook's conclusions, therefore, were that the retention of overage pupils reduces the mean intelligence of classes and lowers the achievement average, and that pupils with equal mental ability do not achieve more in schools with higher standards

28

Walter W. Cook, "Some Effects of the Maintenance of High Standards of Promotion", Elementary School Journal, 41:430-37, (February, 1941). 
of promotion.

The psychologists's viewpoint on the effects of too

much failure was given in the following excerpt from Jor29

dan's book. He was discussing the impulse of mastery.

"One of the habits intertwined with this work by past successes. If a child has had the work so carefully graded that he has rarely felt the sting of failure, he is spurred on to the very limit of his ability. On the other hand, there is nothing which dejects school children quite so much as failure. Once they get behind to any particular extent, their mastery impulse is not definitely stimulated. They then try to express their personalities in another line. Thwarted in its impulse towards mastery in one direction, this impulse may appear in another." 30

The author stated ways in which this thwarted mastery impulse might reappear. He suggested that the older boy who has failed may bully the younger children and that an older girl might appear in flashy clothes.

Later in he book he made another statement about failure. "Probably in no way can the feeling of inferiority be increased more than in providing situations in which a child not only fails but continues to fail."

\section{9}

Arthur M. Jordan, Educational Psychology, (New York Holt and Company, 1934), pp.522.

30

Ibid., p. 60 .

31

Ibid., 0.459 . 
32

Haggerty showed a graph of the undesirable behavior of eight hundred elementary school children. He stated that retardation seemed to have a bad effect upon behavior or at least the two showed a high relationship.

Certainly the largest number of recent studies showed that the disadvantages of school failure far outweighed the advantages. However, the real problem was still failure prevention. This was attacked in numerous ways which will be reviewed in the next section.

The prevention of failure. Early studies made clear that legislative reforms on a state or national basis were necessary to correct some of the evils leading to retardation. The school attendance laws which were adrocated at that time have been passed but are not always enforced. An adequate school census was recommended. That, too, has been provided. Laws governing child health have been passed throughout the country.

All types of school accounting have been improved. $T_{h}$ system now used in Louisville to record attendance is nation-wide. Standardized forms are now available for all kinds of school records. Education text books have been written on the subject of record keeping. These forms have

32

M. E. Haggerty, "Incidence of Undesirable Behavior in Public School Children", Journal of Educational Research, 12:102-22, 1925. 
have erased the earliest suggested causes for failure. Hundreds of other theories as to methods of failure prevention appeared in educational publications. These vame under two heads: (I) those that were the responsibility of the administrator, (2) those that were the responsibility of the teacher.

Methods of failure prevention which were the responsibility of the administrator will be listed first.

Whether to promote annually or semi-annually had to be determined by the superintendent. Other procedures were sending questionnaires for teachers to fill out before failing children, provision for adequate teaching equipment, for a school health program and for a visiting teacher service, establishment of a central bureau for special testing and research, of reading clinics and of a general school testing program using standardized test.

Adequate record systems which make available such statistics as age-grade data and cumulative case studies on individual children were found necessary. The good administrator provided summer school if the need appeared and might also establish special classes for coaching, for the mentally retarded, for foreign language groups and for children with physical defects.

Administrative provision was made in certain schools for slow-moving children by the establishment of mental age 
norms for advance dates, by setting up special plans for the primary group or by establishing such plans as the Winnetka system, or the Dalton system, in all the schools. Promotion by subjects was tried in some places and trial promotions in others. Appointment of committees to work out a differential course of study was another administrative problem. Although all the methods of failure prevention which have just been listed were responsibilities of the administrator, much of the responsibility, as many studies pointed out, was borne by the classroom teacher. Here then we have methods of failure prevention recommended to the teacher. The cry throughout was for increased individual instruction. Some authors gave recommendations for exact procedures in certain subjects. Several suggested special instruction for the child who has been necessarily absent.

Building correct attitudes toward school and work was suggested as a method a teacher might use for failure prevention. In this same field, attention to behavior problems as such, rather than confusing them with academic difficulties, was cited as a helpful procedure.

Many general lists appeared in the literature giving some suggestions applicable to administrators and some to teachers in the work of failure prevention. 
33

The Ninth Yearbook of the Department of Superintendents gave such a list of means of reducing failure in elementary and secondary schools. The ten with highest mention are given here and are ranked in order of frequency of mention by 555 superintendents of schools.

\section{TABIE III}

MEANS OF REDUCING FAILURE AS LISTED BY 555 SUPERINTENDENTS

1. Using achievement and diagnostic tests No. Choosing Means followed up by special help and remedial work. 374

2. Giving individual attention to pupil needs and interests.

3. Grouping according to ability, providing differentiated courses of study, and applying teaching methods suitable to each ability level.

4. Keeping work within the grasp of the pupil 175

5. Learning about pupil's home conditions, and securing the cooperation of the parents.

6. Diagnosing reading difficulties of individual pupils and giving remedial work.

7. Creating an esprit de corps.

8. Improving teaching methods.

9. Providing thorough, purposeful and activated drill for accuracy.

10. Teaching pupils how to study, and how to organize their work.

\section{3}

David E. Wegleiss and others, "Promotion Problems from Kindergarten Through Graduate School", Ninth Yearbook of the Department of Superintendents of the National Education Association, February, 1931, pp.17-149. 
In some cases evidence was presented for the conclusions shown in such lists. These studies will be reviewed here beginning with those on controversial questions of ability grouping. Reams have been written for and against homogeneous grouping. Some of this material will be considered in a special section on provision for the slow child. 34

Reader quoted a study by Sanvain of the opinions of teachers, administrators and parents as to the desirabilty of ability grouping. This investigator found that the majority of teachers and school officials favored honogeneous grouping according to ability. This was not true of parents.

Hayes' study which has been previously cited seemed to prove that the mental age at time of entrance to the first grade was the most important factor in non-promotion. Her conclusion was that to reduce failure children should be eliminated from school until they were mentally six years of age.

$36 \quad 37 \quad 38$ Gordon, Reinoehl, and Theman all suggested keeping

34

Ward G. Reeder, Fundamentals of Public School Administration,p.503; citing Walter H.Sauvain, A Study of the Opinions of Certain Professional Groups Regarding Homogenvious or ${ }_{\mathrm{Ab}}$ ility Grouping.

Hayes, op.cit., p.28.

${ }^{36}$ Hans G. Gordon, "Promotions", Review of Educational Research, 12:26-31, February,1942.

37

C.M. Reinoehl, "Promotional Units Eliminate Grade Failures", Nation's Schools, 26:70-72, October, 1940 .

38 Viola Theman, "Continuous Progress in School", Childhood Education, 18:21-23, September, 1941. 
young children together was a unit for as long as three years a procedure which would eliminate regular promotions and therefor remove failures due to late maturing. The retention of one teacher for a greater length of time than it is now customary was an integral part of this plan. Such a plan has been tried in Rochester, Los Angeles, Nashville, Minneapolis and Pittsburgh. The first two writers adrocated groupings within the three year range of children similar in chronological age, mental age, abilities and interests, but Theman seemed to think that variations in chronological age might be valuable, and that similar interests were a better basis for grouping. All suggested that a child might leave his unit and move to another when it would be of benefit to him.

Within some systems schools were organized in such a way that children moved at different rates through the grades. Various plans have been suggested and practiced which attempt to make this possible. The Winnetka plan and the Dalton plan were two such methods of individual instruction. In the Winnetka plan the child was given opportunity to complete certain units of instruction, proceeding as fast as he was able. When he had finished one unit he checked it with an answer sheet and if it was correct moved to the next. If not he went back to work again on his errors. These units were derived from drill subjects. Group activities took care of other phases of the school work. 
The children were divided into grade groups according to chronological age. As this plan was carried out in Winnetka, Illinois a child might sit for two years in a second grade room. Washburne explained this practice as follows:

If their intelligence tests scores and their school progress show that they will probably need seven years to complete the work of the first six grades, they sit a second year in the so-called second grade room. They do not, however, repeat any second grade work that they may have completed. They simply go in September from where they left off in June. Sooner or later such children are bound to have the disappointment of sitting two years in the same room. We feel that this disappointment is less keen at the second grade level than later, and that it will be better for them to be habitually somewhat ahead of the children in the group than discouraged by slipping further and farther behind.

The Dalton plan allowed for individual progress, also. It differed from the Winnetka plan in the necessity for the child to finish all his "contracts" for one grade before he could move to the next.

Knudson and Stenquist suggested a reorganization p.189. Carleton Washburne, Adjusting the School to the Child, 40

K. 0.Knudson, "Program for tilimination of $\mathrm{F}_{\mathrm{a}}$ ilures in Elementary Schools", Elementary School Journal, 38:729-30, June, 1938. 41

John L. Stenquist, "How Baltimore Handles Pupil Promotions", Nation's Schools, 27: 41-44, January, 1941. 
into $C, B$, and $A$ divisions within a grade rather than the customary $B$ and $A$. The average and bright child could move quickly through $\mathrm{C}$ or, as the system is worked out in Baltimore, he could move through without ever entering a $C$ group. The plan in Baltinore sent the children through the elementary schools in three ability groups with special provision for each. This is the way it worked out for the first three grades:

\section{TABLE IV}

BALTIMORE PLAN FOR MOVEMENT THROUGH THE GRADES

\begin{tabular}{lllllllll}
$\begin{array}{c}\text { First Year } \\
\text { of school }\end{array}$ & Second & & Third & & Fourth \\
\hline IC & $1 B$ & IA & 2C & $\begin{array}{llllll}\text { SIow } & 2 A & 3 B & 3 A\end{array}$
\end{tabular}

IB $\quad$ IA $\quad 2 \mathrm{~B} \quad \stackrel{\text { Average }}{2 \mathrm{~A}} \quad 3 \mathrm{~B} \quad 3 \mathrm{~A}$

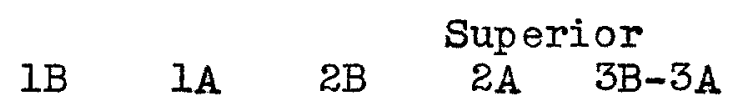

In these ways, then, reorganization of the classification of pupils and of work assignments may allow for individual progress and thus reduce the amount of failure.

Ibid., p. 41 . 
Numerous investigators reported upon the efeects of 43

trial promotions as a failure prevention. Buckingham described such an experiment in the schools of Springfield and Decatur, Illinois. The influenza epidemic of 1918 had caused excessive absence in the schools of these two cities. The failure lists were long. The administrators saw that the children could not be held to the usual standards so, after due deliberation, decided on provisional promotions as the best solution of the problem.

All the pupils were promoted to the next higher grade. Those who had been recommended for failure were given special attention. The receiving teacher was given six weeks to decide whether the child was capable of doing the work of the grade. All the responsibility was put on the receiving teacher. She kept careful record of the pupil's work during the probationary period and of her own efforts to help him. She visited his home, interviewed his parents, gave outside help and extra homework wherever necessary.

The results were astounding. At the end of six weeks seventy-five percent could be retained in the higher grades. At the end of the semester more than half of the failure list were recommended for unconditional promotion.

B. R. Buckingham, "An Experiment in Promotion", Journal of Educational Research, 3:326-36, May, 1921 . 
44

Heck noted that in a trial promotion experiment in Cuyahoga, Ohio seventy-one percent of the children made good. 45 Myers told of a decision to promote automatically all the children of Mason School in Omaha, Nebraska. Children who would formerly have been failures were spoken of as "adjusted" children, since the work had to be adjusted for them in each grade. At the end of the experiment the cards of the 198 of the first "adjusted" children who were still enrolled were carefully studied.

It was found that 40 percent of the children had attained nornal progress within one school year, more than 15 percent within two years, more than 8 percent within three years, 4 percent within four Jears, and 2 percent within five years. Twenty-eight per cent were still "adjusted" at the end of the study. A number of the original failure group became superiot students. The experiment seemed to show the time element important in the adjustment of children.

Within these trial promotion schemes in most cases were plans for a differentiated course of study for the 44 Heck, op.cit. pp. 373-74, citing Vivian Klene and E.P.
Branson, "Trial Promotion Versus Failure", Educational Research Branson, "Trial Promotion Versus Failure", Educational Resea
Bulletin of Los Angeles, California, 8:6-i1, January, 1929. 45 Fanny Myers, "We Experiment With a Non-Failure Program", Childhood Education, 18:205-9, January, 1942. 
46

children who would have failed. Judd felt that changes in the course of study to suit certain age groups and individuals were one of the best means to reduce the amount of failure. Throughour most systems in the country some of these changes have been made within the last ten years and this has probably invalidated the statistics he recorded in reading, arithmetic and their correlation with mental ability. Changes in the course of study or a varying of its requirements depending on the ability of the child left the teacher free to teach the child as an individual. Hartwell suggested that at least one half hour a day should be devoted to individual work by the teacher. He suggested promotion by subjects as a further atep in meeting the problem of the variation of abilities.

Strayer and Engelhard spoke strongly on the part the teacher played in this method of reducing failure.

The teacher who would do his work intelligebtly must from the very first day of school think in terms of the individual

46

Judd, op.cit., p.19.

47

Charles S. Hatrwell, "Grading and Promotion of Pupils", National Education Addresses and Proceedings for 1910,pp.294-300.

48

George D. Strayer, and N.I. Ingelhard, The Classroom Teacher, (New York: American Book Company, 1920) pp. 400 . 
differences of the pupils of his class group. He must learn to measure such differences scientifically so that each child may be accorded the attention and care which will permit his progress with the utmost rapidity. 49

otto cited reports from 493 superintendents of schools giving arithmetic and reading as the subjects in which the failures were found. He advocated more attention to these particular subjects and better individual instruction to reduce the number of failures. Bell ${ }^{50}$ stressed the need for careful individual assignments where the child must be absent. 51

Sumption seemed to summarize the opinions of many educators when he said:

Studies indicate that, regardless of the promotional plan in use, curriषulum adjustments brsed on individual case study holds the greatest hope of success in re ducing student failure.

There are, then, many ways to to about reducing the 52

amount of failure. Hawley and Peckstein suggest that perhaps

Henry J. Otto, "Pupil Failure as an Administrative Device", Elementary School Journal, 34:576-589, April, 1934.

50

John Bell, "Failure Prevention", Cleaning House, 15:134-47, November, 1940.

51

Sumption, op.cit., p.1057.

52

Hawley, and L.A.Peckstein, "Diminishing Returns in Non-Promotion", Elementary School Journal, 22:584-96, April,1922. 
the easiest for the administration to say, "Let there be promotion". Some systems have tried this method. However, no thinking person could accept that plan unaccompanied by other methods to help the child to adjust to such a regime. Some of those methods listed in the next paragraph as advocated by certain writers have been treated more fully in the preceding pages.

Levy had a remedy for each of the causes of failure which are comnonly named in non-promotion studies. He said to combat lack of interest improve methods and vitalize subject matter. If poor home conditions were the cause, enlisting helpful agencies should be the procedure. If the child suffered from undernourishment and lack of rest he suggested that teaching the principles of diet and rest, and checking to see that they are carried out would be possible. Much absence can be cured by finding the causes and taking steps to remove such causes. A plan for checking to see that all work missed is made up is another part of this. If unwise previous promotion seemed the reason for failure, a study of marking technique, with erequent objective tests, might help. A child who is confused might be helped by an elimination of non-essentials. Cooperation between home and school would remove the feeling of conflict in the child, 53

Muriel M. Levy, "What Price Failure", School and Society, 47:766-68, June 11, 1938 . 
while fair play and methods adapted to the class would remove a feeling of dissatisfaction with the teacher. This author concluded that interesting the child was the strongest factor in failure prevention.

Two studies gave lists of procedures they had followed in reducing the amount of failure in two widely separated places. Phifer stated that in Fayetteville, North Carolina they used homogeneous grouping, trained leaders for lower groups, a city-wide drive for better attendance, a stimulation of interest through club groups, and loose grouping in the first three grades as failure preventions. A special report of the Board of Education of New York City stressed a drop in amount of retardation from 45.99 per cent in 1921 to 27.56 per cent in 1934. The reasons given were special classes, modifying procedures and achievement standards, improving methods and materials of instruction and raising teaching standards.

This report published in 1938 made clear that there was much yet to be done in the field of failure prevention.

Juliette V. Phifer, "Steps Toward Better School Iife for Retarded Pupils", School nd Society, 56:387-88,0ctober 24, 1942. 55

Report and Recommendations of the Jpint Committee on Maladjustment and Delinquency, Board of Education, city of New York, January, 1938, pp.127. 
Practically all the studies brought out this point. Per cents of retardation and failure have dropped considerably in the last twenty years, but they are still high enough to be a reflection of the lack of thought given to the individual child. They show plainly that with some types of children educators are still as confused as they were at the beginning of the century.

The slow learning and mentally retarded child. One type of child who was asked to repeat was the child who was, according to modern methods of testing, slow learning or mentally retarded. Since his mental age level was below that of the average child in his grade he was incapable of fulfilling the academic requirements which were set for average and above average emntalities. He was therefore often asked to repeat the grade in the belief that another term or year in the same grade might bring his achievement nearer to the grade level. Some educators were convinced that this was a poor method of adjustment and a harmful one to the individual. They suggested other ways of meeting the problem. These were reviewed in the books and periodicals here presented.

The argument as to whether such children should be separated from their regular class groups and put in special classes was part of the problem of the proper education of

56

Bernadine G. Schmidt, "Cureent Administrative Practices in Educational Provision for the Mentally Retarded", Educational Administration and Supervision, 28:541-45, october, 1942 . 
56

the mentally retarded. As Schmidt said, the large numbers of these children made some provision for group teaching necessary although the necessity for their individual treatment was an accepted fact with most school teachers and administrators. This author stated further that the argument for and against homogeneous grouping was really an outward expression of two different underlying philosophies - the passive transmission of subject matter versus democratic participation in the changing problems of a dynamic cooperative society. She reviewed the three possibilities, if the child was taken from his own classroom, a special class within the regular school, total segregation in special schools, or the placing in a special class in another lementary school. There were, according to this writer, four types of children who required this special grouping. They were first the non-academic, the children who were not mentally deficient, but whose ability and interests lie in the technical arts. The she mentioned the asademically retarded. The third group was the slow learning, whose intelligence quotients ranged from seventy to ninety. The fourth group was the mentally retarded with I.Q.'s brlow She concluded her article by stating that keeping deviates

Bernadine G. Schmidt, "Cureent Administrative Practices in Educational Provision for the Mentally Retarded", Educational Administration and Supervision 28:54l-45, 0ctober, 1942 . 
in regular classrooms eliminated much administrative detail but required more and abler supervision of teachers.

Mort stated that the group with low mental ability should be classified soon after entering school and have an educational program fitted to its needs. He adrocated special grouping throught junior high school to accomplish the latter aim. He felt, however, that there was much yet to be done in planning courses of study for this group. The customary procedure in classes of the slow learning or mentally retarded is to take as much as fifty per cent more time to accomplish the same ends as the regular six grades. This is to him a wrong procedure. He advocated eocational training, attention to community civics, less highly developed skills and less extensive knowledge for this group than for the norman group. He suggested a special certificate of promotion for them on finishing the eighth grade or junior high school. He noticed that senior and junior high schools were beginning to take for granted the necessity for remedial work to aid the group which come to them from lower schools.

57

Paul Mort, The Individual Pupil (New York City, American Book Company, 1928), pp.160-61. 
This statement was in line with one of Garrison's that records show decreasing average mental ability of entering high school pupils. This he says is due to two factors; the increased holding power of the schools and the drop in numbers of failures. He quoted Portenier to show one school system reporting that over the period of ten years between 1921 and 1931 mental ability of the entering class dropped one year. Garrison said that in the typical American public school 17 per cent or more of the pupils finished the first grade unable to read first grade material without help and that by the end of the third grade 40 per cent of all the pupils fell below the norms required for handing fourth grade reading without handicap. He said, "Failure to make curricula provision for these boys and girls may prove costly not only to the school and to the individual but to society at large". Hildreth reminded the educator, however, that these

\section{8}

Karl C. Garrison,Psychology of Exceptional Children, (New York: Ronald Press Company, 1940) p.

59

Ibid., p.159, citing L.G.Portenier, Pupils of Low Mentality in High Schools (New York:Teachers College,Columbia 1933).

60 61 Garrison, op.cit., p.197.

Gertrude Hildreth, "Educational Provision for the Slow Learning Pupil", Educational Administration and Supervision, 25:491-512, october, 1939. 
slow learners were sometimes hard to identify in the early stages of their development. She reported that surveys showed that this group formed from fifteen to twenty per cent of the total school population. They made up the overage population of our schools and were slow learners throughout their school career. They were reported more often as disability cases in reading and most of the remedial effort was expended in their behalf. They were the group from whom juvenile delinquents most frequently came and later constituted the unstable factor in business and industry. They came for the most part from under-privileged homes where marginal economic conditions prevailed.

Questionnaires were sent to thirty-three cities of over 100,000 population. From the first group of cities, twentyeight answers were received and from the second group twentyone. These answers showed an alertness on the part of school people to the problem. Individual work was common. Activity work had been introduced and less dependence was put on a Mbasal" textbook. However, Miss Hildreth judged the efforts expended as a whole to be temporary and superficial. The tendency to dump slow children into easier courses such as art and home economics she called reprehensible. She saw a need for further soolal, cultural and appreciative development and much greater guidance. 
62

Beals wrote aterrible indictment against the use of failure as an adjustment for the slow learning child. To quote him,

The law forces Henry to go to school but provides nothing for him when he gets there. . .

Because of his continuous failure he lacks confidence in himself; his potential abilities have not been developed. He has not learned to cooperate with others or to do his part in a group activity. Henry has been cheated of his right in this democracy which aims to educate all the children of all the people. Education has failed to develop his potential capacities and has hindered rather than advanced his chance of becoming a happy, useful citizen. Failure in school has virtually taught him that he cannot succed. 63

Beals cited the classes for retarded children in Chicago as examples of correct provision for the Henrys of the school systems. These were arranged according to the age of the children. At twelve they were promoted from ungraded classes to lower vocational centers. They worked in a shop for at least one hour a day. They learned to use tools. The boys learned household repairs and the girls cooking and sewing. The dignity of labor was continually stressed with this group.

\section{2}

Frank L. Beals, "Educating the Slow Child", Part I, Hygeia, 20:876-77, November, 1942.

63

Frank L. Beals, "Educating the Slow Child", Part II, Hygeia, 20:956, December, 1942. 
At sixteen they could leave school, but there were definite things that these children had learned by this time. They had learned to make the most of their personal appearance; they could read, write and spell. They had been taught to use the post office, banks, and stores, how to apply for a job, and how to fill out blanks. They had developed emotional stability, good work habits, honesty, courtesy and cooperation. This author considered such training worth the cost because the children were taught to be self-supporting and would not therefore become dependents on their cammunity. We have become more conscious of this group during the war emergency when even the "mentally retarded" is valuable if he can be used anywhere on the production line.

Even such long lists of accomplishments were not enough 64 to convince the exponents of heterogeneous grouping. Lee reviewed Pertsche's study in which the latter reported experimentation with two groups of sub-normal children; one segregated and the other non-segregated. He found the non-segregated group had higher academic achievement over a given period.

64

John L. Lee, "Special Schools and Classes", Review of Educational Research, 9:180-84, 234-36, April, 1939, citing Christopher E. Pertsche, A Comparative Study of the Progress of Sub-normal Bupils in the Grades and in Special Classes, Doctor's Dissertation, Teachers' College, Columbia University, New York City, 1936. 
65

Emery reported his observations in many "opportunity" rooms. He observed three of these frequently as they were in his own school. He was convinced that the slow learner was better off in a regular classroom. He listed the following objections to ability grouping. The child cannot be segregated in real life. Disciplinary difficulties were concentrated where low ability children were put in one room. This type of set-up was practical only with large schools. It was an expensive type of education when per capita cost was considered. It demanded teachers of the highest type. 66

Featherstone, who had the major responsibility in planning and developing the speyer school experiment with slow learning pupils, warned that segregation was not enough, but that drastic changes in the curriculum were necessary. He asked that the administrator make sure of good teachers, community approval, absence of tendency to exaggerate the importance of slow learningness, and restraint in using special classes as place for misfits, before he even attempted such grouping.

\section{5}

James N. Bmery, "That Opportunity Group", American School Board Journal, $96: 43$, June, 1938.

66

W. B. Featherstone, "Teaching the slow Learner", (No.I, Hollish. Caswell, editor, Practical Suggestions for Teaching, New York: Teachers' College, Columbia University,1941) p.23. 
67

Terman begged for a sympathetic and intelligent approach to the problem of the slow learner. He said,

It should be clearly understood that individuals of inferior intelligence are not necessarily undesirable members of society. Indeed the world has abundant use for them. A large proportion of the tasks in the modern organization of industries can be as well performed by individuals of the 70 or 75 I. Q. class as by those of superior intellizence, and with more satisfaction in the performance.

He stressed, however, that to make the most of this type of ability it must be trained. He warned that segregation accomplished nothing but relief to the regular teacher unless such classes had a special curriculum, suited to the needs of the slow learner. He advocated vocational training for the 70-80 I.Q.'s. He cited the example of one sixteenyear-old with an I. Q. of 74 who left school with the ability to read, write, and do the fundamental operations in arithmetic. He had not been trained for any of the semi-skilled jobs in which he might have succeeded.

An article by Mones discussed an experiment with

Lewis M. Terman, Intelligence of School Children, (Houghton-Mifflin, Boston, 19197, p.288.

68

Leon Mones, "Cleveland Junior High Develops Courses for Binet Low I.Q. Pupils", Clearing House, 14:451-57, April, 1940. 
pupils of low I.Q. in the Cleveland Junior High in Newark, New Jersey. He felt the experiment was most successful and proved that there was a place in junior high school for children of that age range and low mental ability. The greatest gain academically was in reading, but he thought the gain in social attitudes and behavior was the most important outcome. At the time he wrote the article the plan was under consideration to send a low I. Q. group on to a senior high school for a year's try there.

These studies then show evidence of thought as to the proper treatment of the slow learning children who always form a large percentage of any given group of failures. The greater number of authors-quoted seemed to show an agreement in their opinions that ability grouping with a vastly dissimilar type of curriculum for the low ability group is the best means of failure prevention for the mentally retarded. They seemed to think provision through the high school years should be made for these children and some authors showed evidence of the successful use of such grouping. They did note, however the cost of such precedures, and the difficulty in obtaining the proper teachers. 
The sex of the child as a factor in failure. A few studies found the sex of the child an important enough factor 69 in failure to give it consideration. St. John studied a school system in a residential suburb of Boston. There were 500 boys and 450 girls in the sixteen school considered. There were 150 different teachers in the four year period recorded. The results of the study showed the boys 7 per cent worse than the girls in grade progress. There were more boys retarded and fewer accelerated. The boys were below the girls in achievement generally, but father below where achievement was measured by teqchers' marks. The correlation of "conduct" and "effort" with marks was greater for boys than girls. The author concluded that the reason for the boys' inferiority to the girls in progress and achievement was to be found in the maladjustment between the boys and their teachers who are all women. He inferred that the teachers failed to adjust themselves and their procedures to the interests, attitudes and behavior of the boys as well as they did to those of the girls.

70

Freeman bears out St. John's statement that the lower

${ }^{69}$ Charles W. St.John, "Waladjustment of Boys in Certain Elementary Grades", Educational Administration and Supervision, 18:659-72, December, 1932.

70

Frank S. Freeman, Individual Differences,pp.200-218. 
achievement record of the boys cannot be blamed on lower ability of the boys. He summarizes a few specific abilities in either sex which affect achievement. Females show a small linguistic superiority, but males show slight difference in their favor in arithmetical ability. Females seem to show superiority in acts requiring memory, but males excel in manual performance and mechanical ability. Boys do better after the age of none in informational subjects such as history, science, and geography, but that is because they read more of that type of material while the girls read more fiction.

$$
71
$$

Another study gave a survey of many statistics derived from intelligence test scores. These authors concluded that no great difference between the sexes either in average tendency or in variation appeared in these statistics. They made the statement that these facts substantiated the inions held by psychologists.

$$
72
$$

Terman stated, however, that the school performance of boys was more easily affected by physical or emotional defects that of girls. He found that teachers more often misunderstood boys and underrated their school work. He felt

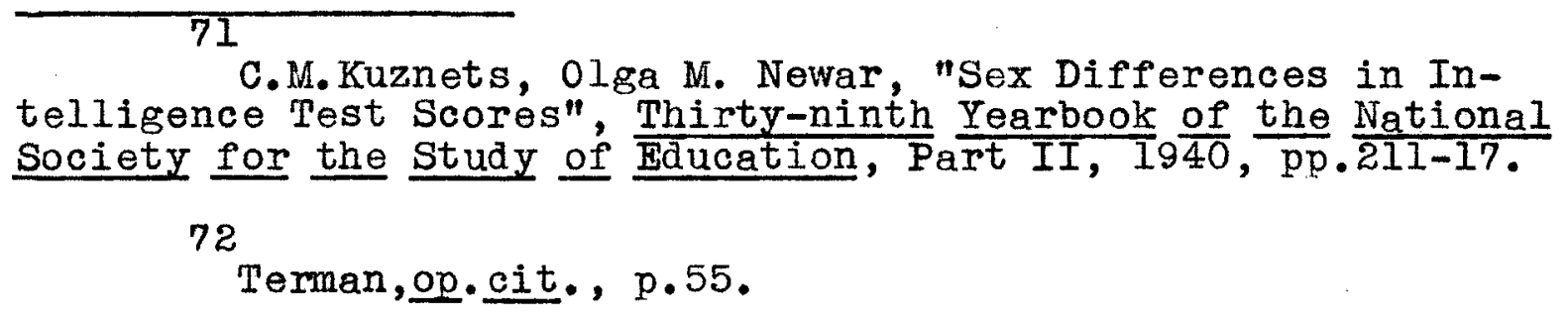
telligence Test Scores", Thirty-ninth Yearbook of the National

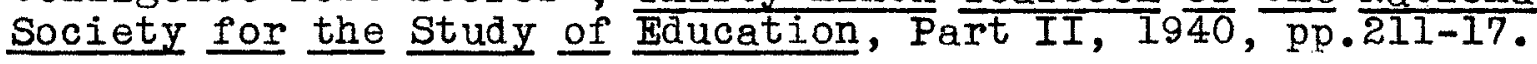

72 Terman, op. cit., p.55. 
that this may be largely explained by the fact that most of their teachers were women. He gave these two points to explain the greater discrepancy he found between I. Q.' $s$ and teachers' marks among the boys. 73

Cornell was interested in the same problem. She studied the records of 749 pupils' which were available to her through the Educational Measurements Board of the New York State Department of Education. These children's records were there in order that they might be reviewed for possible assignment to special classes. They had been selected for lack of school progress. Cornell found that seventy per cent of the group were boys.

The conclusions from this study were as follows: There were more boys in the group than girls because boys become retarded at a mental level nearer the average. Girls could express themselves better linguistically and learned to read more easily. The chief ability in which the boys showed superiority--the ability to manipulate concrete things--might put them at a decided disadvantage in most schools. The boys tended to show greater instability and decided positiveness of personal traits. These two factors perhaps helped them to become maladjusted more easily.

Ethel L. Cornell, "Why Are More Boys Than Girls Retarded in School?" Elementary School Journa1, 29:96-106, 1928. 
The consideration of various failure studies showed that the factor of the sex of the child and of the teacher did enter into the number of failures. Later in this study it will be shown how it was noticeable in statistics from the Louisville schools.

Various points of view on failure. Quite early in this chapter the statement was made that the point of view about failure of the administrator or teacher was of great importance because his procedures were apt to follow his point of view closely. Several studies mentioned the fact, however, that many more administrators claimed a belief in one hundred per cent promotion than carried it out. A review of the points of various educators seemed worth while in concluding this chapter.

74

Hawley and Pechstein took the viewpoint that failure was acceptable for the backward pupil who could not do the work of the next grade provided he did not become greatly overage for his grade. They felt that the needs of slower pupils could be met in part by repetition. They seemed to stand firmly against failure of the normally intelligent.

\footnotetext{
74

Hawley and Pechstein, op.cit., p.594.
} 
75

Asfahl took for granted that there would always be a large amount of failure in the lower grades. He was convinced that the problem of maturation made this necessary. He stated that failure should be rare after the fourth or fifth grades.

Emery insisted that it was not fair to the hardworking to let the lazy children pass. He said that these children's hearts woula not break, that it wä not realiy fair to them to send them along when they were not ready for it. 77

Coates wrote quite an indictment of the one hundred per cent promotion idea. He resented that the child's acts or failure to act in later life were often blamed on school failure. He called "maudin" the educational philosophy that considered the child's home background before' marking him. $\mathrm{H}_{e}$ said that repetition in life was not called failure, but that we only failed in life when we gave up our enterprise. He felt that promotion without the feeling of complete mastery of the subject is a tragedy. He gave as fair reasons for failure lack of study, lack of attention, poor previous preparation, or even personal problems.

\section{W5.D.Asfahl, "Board of Education Considers Retardation}

and Promotion", American School Board Journal, 102:3-31, Hay, 1941

76

James N. Emery, "When Johnny Doesn't Pass", Journal of Education, 125:86-87, March, 1942.

77

Mary Weld Coates, "Democracy and Student Failures", School and Society, 52:398-400, October 25,1940. 
Many writer took the opposite viewpoint from the one just stated. They thought that failure should be considerably lessened or in some sases completely eliminated. As far back 78 as 1909 we found Ayres expressing the belief that other things being equal, the best school was one which regularly promoted and finally graduated the largest percentage of its pupils. He campaigned lustily for the establishment of self-confidence and a feeling of success in children's minds. He felt that they would accomplish far more than children with greater intellectual achievement, but the habit of failure well-fixed in their lives.

The large number of overage children who were misfits 79 in their present grades was discussed by Mort. He counted as failure what the school has done rather than what the children have undergone. He was particularly indignant over the group of children of junior high school age who were still sitting in elementary classrooms, when they needed so bady the things the junior high school had to give. He ended by stressing the point that when an educator really knew where

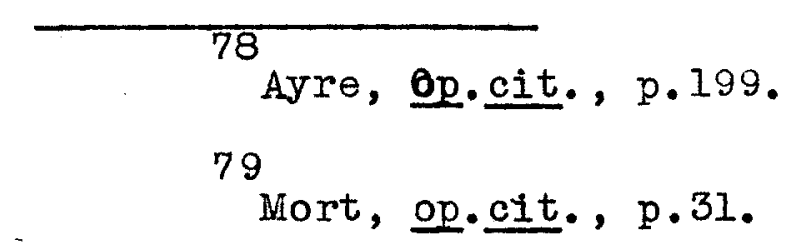


a pupil stood it was seldom that a better plan than repeating a grade could not be evolved.

The teacher's lack of understanding of the potency of the weapon of failure received some thought in Caswell's article, too. He insisted on the adjustment of standards to the ability of the child in the schools of a democracy. 81

Sumption, in reviewing the recent literature on nonpromotion, stated that the present trend is to adjust the curriculum to the pupil rather then to fail pupils in order to adjust them to the curriculum. He gave evidence from psychological research to enforce his belief that failure, a form of reproof, is much less effective than praise for the below-average group. He cited the possibilities for the development of problem cases as a result of ridicule on the part of other children. He insisted that instruction really adapted to individual differences would present no occasion for retardation.

The artificiality of our grade system was scored by

80

Caswell, op.cit., pp.92-93.

81

Sumption, op.cit., p.1057. 
82

Buckingham. He felt that once having established it we clung to it and large numbers of failures resulted. In other writings he underscored his belief that the failure was always the school's. He said that it inight not be the school's fault as it is set up, but is still the school's failure.

Rivolin attacked the same problem but expressed his ideas positively rather than negatively. He begged the teacher to work for the wholesome development of students' personalities by being a good teacher. He felt that any inethod that gave the pupils a feeling of success in their school work and reduced the emotional shock of failure was aiding emotional adjustment.

Ellsbree admitted thatsome failure experiences in Iife led to growth, but he did not believe that repeating of a school grade was such an experience. It might produce discouragement and despair and any experience that does so is no longer educative. If a person is to learn from failure he must understand its cause and how to overcome it. Elementary

\footnotetext{
82

Buckingham, op.cit. , p. 330

83

Ibid., p.19.

84

H. N.Rivolin, Educating for Adjustment, pp.368-83. 85

Willard S. Ellsbree, "School Practices that Help and Hurt Personality", Childhood Education, 18: 197-204.
} 
school children seldom realize the complicated series of events leading yp to non-promotion.

The importance of the right level of aspiration for each child was the theme of Barker's article. He stated that the feeling of success or failure within an individual was independent of actual achievement but determined by the level of aspiration of the person at the time of the failure. This level of aspiration could be thrown out of balance by continous failure. It might be much higher than the child's possible achievement or much lower. Children who had continuously succeeded were more apt to set aspirations at a realistic level. A feeling of success, this writer thought, should be possible for every child at his own level of achievement.

87

Haggerty found large numbers of behavior problems in overage and retarded groups. He questioned the value of the exacting demands put upon this group by the school organization, when the results seemed to be social maladjustment.

\footnotetext{
86

- Roger C. Barker, "Success and Failure in the Classroom", Progressive Education, 19:221-24, April, 1942.
}

87

Haggerty, op.cit., p.112 
The importance of the adolescent entering junior high school at the proper time was mentioned by otto. He then - launched into a diatribe against adjustment by failure in the following rords:
The interesting feature is that fixed curriculum content prescribed for spe- cific grades is one of the things which makes schools formalized and results in heavy pupil mortality. ... There is nothing particularly sacred about the allocation of a given unit of content to a specific grade, nor is the grade in which apaeticular unit is taught particularly significant. The mental development of the child is a more important consideration. 89

He said further that the aim at all times shoud be to provide class groups in which children of about the same age and maturity may participate in educative experiences. No child should ever be placed in a situation in which he will develop defense mechanisms or undesirable traits of character or personality.

Some $_{90}$ writers gave evidence for and against failure. Brueckner, after some investigations in New York arrived at

88

otto, op.cit., p. 220. (Elementary School Organization and Administration.)

89 Ibid., p.225.

90

Brueckner, The Changing Elementary School, The Regent's Inquiry, pp. 72-97. 
the conclusion that basing promotion on state standards was unfair to the individual child but that failure due to excessive absence, general social and physical immaturity, or lack of progress, was justifiable.

\section{1}

The Committee on Promotion Problems from the Department of Superintendents delared that promotion should be on the basis of the individual pupil, depending not only on his academic achievement but on what would be best for his allround development. They considered such factors as need for further courses for mastery of the subject, certain subject matter requirements, need for flexible administrative set-up, harm to other pupils resulting from promotion of pupil, necessity for sufficient space for all, cooperativeness as a requirement for teachers under such a plan. 92

Heck, too, asked that the teacher consider the child's further need of a subject before failing him. He begged that hse have a complete knowledge of the child. He expressed the belief that under the present set-up the child received no

\footnotetext{
91

D. E.Wegleiss, H.M.Corning, G.D.Taylor, H.S.Weet, "Promotion Problems from Kindergarten Through Graduate School", Ninth Year Book of the Department of Superintendents of the National Education Association, February, 1931, pp.17-I49.

92 Heck, op. cit., p.382.
} 
credit for what he had done. He was merely asked to repeat. Failure, according to Heck, should be the exception and not the rule.

A group of superintendents in Northern Illinois expressed their points of view about promotion. These are recorded by otto. Thirty-three per cent felt that every child shoudl be promoted regularly if at all possible. Seventeen per cent determined pupil placement by chronological age, social maturity, and scholastic attainment. Seventeen per cent expressed as their policy one which aimed to keep pupils in the habit of success. Thirteen per cent based promotion on the child's application to his work. Ten per cent held to minimum essentials and 10 percent counted some subjects as majors and some as minors. In their systems they also "lifted" overage repeaters a grade or more.

Here, then, we have opinions on promotion and failure as expressed by educators in various fields. The largest number seemed to advocate elimination of failure entirely or reducing it to a minimum. Teachers, administrators, writers, in the field of education have all expressed themselves wolubly on this subject within the last thirty years. In more and more cases statistics show that procedures are beginning

otto, op.cit., pp.22-25; (Promotion Policies and Practices in Elementary Schools.) 
to follow these stated points of view as age-grade studies and promotion percentages show greatly reduced amounts of failure

Absence of such studies in Louisville. In conducting research for non-promotion studies in our own city, no detailed study was found. The sqperintendents' reports for the various years revealed statistics on promotion percentages by subject and grade. The data from this source applicable to this paper will be given in chart in a later chapter.

A recent school survey conducted by a group of educators at the request of the city government used this same data and made a few applications of the results. This too will be quoted in full later.

Aside from these two sources no failure studies based on Louisville seemed to be available. For that reason it seemed of value to make such a study here.

94

George A. Works, Louisville Public School Survey, A Report on the Schools of Louisville, Kentucky, pp.257-260. 
CHAPTER III

FINDINGS ON THE INCIDENCE OF FAILURE IN LOUISVILIE 


\section{FINDINGS ON THE INCIDENCE OF FAILURE IN LOUISVILLE}

Findings on the Louisville Survey. The most recent study of non-promotion in the Louisville schools was that published in the survey of the city schools made by Dr. George A. Works at the request of the City of Louisville and the Board of Education. An attempt was made to determine the promotional policy in Louisville by studying progress data from the sixth grade of Louisville elementary schools. Only children who had spent their entire school life in Louisville were included in the study. No children in special or slow learning classes were included. Of the 3,406 pupils in the sixth grade, 2,199 or 64.5 per cent had spent their entire school life in Louisville. Their rate of progress is shown in the following table.

\section{TABLE $\quad \nabla$}

RATE OF PROGRESS OF 6A AND 6B PUPILS

LOUISVILLE PUBLIC SCHOOLS, 1942-43

Rate of Progress

Normal

Retarded

Accelerated

Total
Number

1210

959

80

2199
Per Cent

$$
55.03
$$

43.61

1.36

100.00 
The mean retardation of retarded pupils was 1.63 years. The mean acceleration of accelerated pupils was 0.6 years.

of the 1,682 white children in the sixth grade in 1942-43, 57.67 per cent had made normal progress, 41.32 per cent were retarded and 1.01 per cent accelerated. Of the 517 negro children in school that year, 46.42 per cent made normal progress, 51.06 per cent were retarded and 2.51 per cent accelerated.

One of the chief causes of retardation is non-promotion. The next table showed a consistent rate of non-promotion except in the $1 B$ and $I A$.

\section{TABLE VI}

PERCENTAGE DISTRIBUTION OT THE INCIDENCE OF RETARDATION BY HALF GRADES

Grades

Per cent of Total Retardation

Grades

Per cent of Total Retardation $\begin{array}{lllllll}7.4 & 7 & 7 & 7.5 & 7 & 2\end{array}$

$\underline{1 B} \quad \underline{A A} \quad \underline{2 B} \quad \underline{2 A} \quad \underline{3 B} \quad \underline{3 A}$ $\begin{array}{llllll}22 & 12 & 8 & 7 & 6 & 7\end{array}$ $\underline{4 B} \quad \underline{4 A} \quad \underline{5 B} \quad \underline{5 A} \quad \underline{6 B} \quad \underline{6 A}$
The survey stated that one result of a policy of retardation was the presence in the elementary grades of many overage children. The point was made that some overageness might 
be caused by late entrance, but that there were, at the time of the study, between five hundred and six hundred pupils in the elementary schools of Louisville who were aged fourteen years or above. Thus number did not include children in ungraded classes.

This research, then, gave evidence of excessive retardation which must be due, at least in part, to non-promotion. other figures on non-promotion were obtained from another type of record which summarized data on the Louisville schools.

Findings for the last five years. The annual reports of the superintendents of schools of Louisville were consulted to see how the schools of this city stood according to promotion percentages by grades. The standing of the $6 \mathrm{~A}$ was, of course, of the greatest interest since this was the grade on which a detailed study was to be made. As it happened, the grade chosen was the one in which there was the smallest amount of failure in the schools of Louisville.

The superintendents' reports for the school years 1937-38, $1938-39,1939-40,1940-41$, and 1941-42 were used to compile Table VII. This table shows the promotion percentages for grades IB through $8 \mathrm{~A}$ for both January and June promotions of the five years studied.

27th Annual Report of the Board of Education, Louisville, Kentucky, pp. 39-42. $\frac{28 \mathrm{th}}{29 \mathrm{th}} \frac{\text { Report }}{\text { Report }}$
$\frac{30 \text { th }}{\text { Beport }}$
31st Report pp. 35-38 pp. 23-26 pp. 57-60 pp. 31-34 


\section{TABLE VII}

PROMOTION PERCENTAGES BY GRADES OF THE ELEMENTARY SCHOOLS AND THE FIRST TWO YEARS OF JUNIOR HIGH SCHOOL OF LOUISVILIE, KEINTUCKY, FOR THE FIVE YEAR BERIOD FROM 1938 - 39 THROUGH 1941 - 42 WHITE SCHOOLS

\begin{tabular}{|c|c|c|c|c|c|c|c|c|}
\hline & $I B$ & $1 \mathrm{~A}$ & $2 B$ & $2 A$ & $3 B$ & $3 A$ & $4 \mathrm{~B}$ & $4 A$ \\
\hline $\begin{array}{c}\text { January } \\
1938\end{array}$ & 84.6 & 90.8 & 94.3 & 92.5 & 95.1 & 94.0 & 97.1 & 96.5 \\
\hline $\begin{array}{l}\text { June } \\
1938\end{array}$ & 84.7 & 90.0 & 93.2 & 93.0 & 95.5 & 94.4 & 96.9 & 96.1 \\
\hline $\begin{array}{c}\text { January } \\
1939\end{array}$ & 84.4 & 90.0 & 93.2 & 93.0 & 95.5 & 94.4 & 96.9 & 96.1 \\
\hline $\begin{array}{l}\text { June } \\
1939\end{array}$ & 84.6 & 91.8 & 91.5 & 93.8 & 92.2 & 95.9 & 93.7 & 95.3 \\
\hline $\begin{array}{c}\text { January } \\
1940\end{array}$ & 81.0 & 85.9 & 91.8 & 89.6 & 94.3 & 92.4 & 95.3 & 94.7 \\
\hline $\begin{array}{l}\text { June } \\
1940\end{array}$ & 81.6 & 90.4 & 90.1 & 92.5 & 90.5 & 94.1 & 92.9 & 95.0 \\
\hline $\begin{array}{c}\text { January } \\
1941\end{array}$ & 81.6 & 87.4 & 90.2 & 91.6 & 93.0 & 93.2 & 94.9 & 95.1 \\
\hline $\begin{array}{l}\text { June } \\
1941\end{array}$ & 80.0 & 88.8 & 88.7 & 91.6 & 87.8 & 93.5 & 92.7 & 95.7 \\
\hline $\begin{array}{c}\text { January } \\
1942\end{array}$ & 81.3 & 87.9 & 90.2 & 89.5 & 92.5 & 98.6 & 95.0 & 94.4 \\
\hline $\begin{array}{l}\text { June } \\
1942\end{array}$ & 81.4 & 89.3 & 86.7 & 91.4 & 87.7 & 92.3 & 91.6 & 95.4 \\
\hline
\end{tabular}

Averages 82.52 89.34 90.79 92.11 92.27 93.79 94.47 95.51 
TABLE VII (continued)

\begin{tabular}{|c|c|c|c|c|c|c|c|c|}
\hline & $\underline{5 B}$ & $5 \mathrm{~A}$ & $6 \mathrm{~B}$ & $6 \mathrm{~A}$ & $7 \mathrm{~B}$ & $7 \mathrm{~A}$ & $8 B$ & $8 \mathrm{~A}$ \\
\hline $\begin{array}{c}\text { January } \\
1938\end{array}$ & 97.4 & 96.4 & 97.6 & 99.0 & 97.2 & 96.7 & 97.0 & 95.8 \\
\hline $\begin{array}{l}\text { June } \\
1938\end{array}$ & 94.7 & 96.4 & 94.5 & 98.3 & 96.7 & 96.4 & 95.6 & 95.9 \\
\hline$\underset{1939}{J \text { anuary }}$ & 95.9 & 95.4 & 97.4 & 98.2 & 96.2 & 94.2 & 97.7 & 97.7 \\
\hline $\begin{array}{l}\text { June } \\
\text { I939 }\end{array}$ & 93.7 & 96.0 & 94.5 & 96.8 & 92.9 & 93.7 & 92.9 & 95.5 \\
\hline $\begin{array}{c}\text { January } \\
1940\end{array}$ & 94.1 & 93.6 & 95.5 & 96.7 & 93.0 & 92.4 & 95.7 & 94.1 \\
\hline $\begin{array}{l}\text { June } \\
1940\end{array}$ & 93.3 & 95.1 & 95.0 & 97.0 & 91.6 & 92.7 & 93.8 & 95.9 \\
\hline $\begin{array}{c}\text { January } \\
1941\end{array}$ & 95.6 & 94.6 & 96.7 & 97.6 & 92.5 & 91.8 & 94.1 & 93.7 \\
\hline $\begin{array}{l}\text { June } \\
1941\end{array}$ & 91.6 & 94.4 & 92.7 & 96.9 & 89.5 & 91.3 & 89.2 & 94.8 \\
\hline $\begin{array}{c}\text { January } \\
1942\end{array}$ & 95.4 & 93.4 & 95.7 & 96.7 & 93.6 & 90.7 & 91.7 & 92.4 \\
\hline $\begin{array}{l}\text { June } \\
1942\end{array}$ & 89.7 & 94.0 & 93.1 & 97.9 & 88.2 & 92.1 & 85.6 & 93.7 \\
\hline
\end{tabular}

Averages $94.14 \quad 94.93 \quad 95.27 \quad 97.41 \quad 93.14 \quad 93.20 \quad 94.33 \quad 94.95$

98

$27 \mathrm{th}, 28 \mathrm{th}, 29 \mathrm{th}, 30 \mathrm{th}, 31$ st Report of Board of Education, loc. cit. 
For every semester listed, the $6 \mathrm{~A}$ showed the highest percentage of promotion of any grade. $T_{h}$ is might have been due to the fact that from the $6 \mathrm{~A}$, children entered a junior high school. The teacher was perhaps more hesitant to hold a child when his group was moving, to a new sohool than she would have been if his group were merely moving to another room in the same building. Whatever the reason, the fact remained that the $6 \mathrm{~A}$ grades showed the highest promotion record of any of the sixteen grade groups listed and showed this record for five years at both January and June promotions.

Perhaps it would be interesting to note the range in failure percentage for this five year period. The promotion percentages were subtracted from one hundred to appear as failure percentages, and the records of the various grades were averaged to obtain the information listed here:

\section{TABLE VIII}

\begin{tabular}{|c|c|c|c|c|c|c|c|c|}
\hline Grades & IB & $1 \mathrm{~A}$ & $2 \mathrm{~B}$ & $2 A$ & $3 B$ & $3 \mathrm{~A}$ & $4 \mathrm{~B}$ & $4 \mathrm{~A}$ \\
\hline Percent & 17.48 & 10.66 & 9.21 & 7.89 & 7.73 & 6.21 & 5.53 & 4.49 \\
\hline Grades & 5B & $5 \mathrm{~A}$ & $6 \mathrm{~B}$ & $6 \mathrm{~A}$ & $7 \mathrm{~B}$ & $7 \mathrm{~A}$ & $8 B$ & 8A \\
\hline ercen & 5.86 & 5.07 & $4 . ?$ & 2.59 & 6.86 & 6.80 & 5.67 & 5.05 \\
\hline
\end{tabular}


The 1B, as already mentioned, showed the largest amount of non-promotion--17.48 per cent for the five yeat period. The 6A showed the smallest amount--2.59 per cent. The grades between showed a gradual decrease, and then the 7B showed a sharp rise, with the average jumping to 6.86 per cent.

Comparison for February and June semesters of 1941-42. Since the statement has already been made that the $6 \mathrm{~A}$ had the smallest percentage of failure for all the five years listed, it is, perhaps, only nedessary to re-state that for the January and June promotions of the year 1941-42, this fact was, of course, also true. This year was the one chosen for a detailed study of the $6 \mathrm{~A}$ failures of Louisville. 
CHAPTER IV

STATUS OF FAILURES USED IN THIS STUDY 


\section{STATUS OF FAILURES USED IN THIS STUDY}

The promotion sheets were consulted to find the number and names of the children failing in the $6 \mathrm{~A}$ grade for the February and June semesters of the year, 1941-42. It was found that there were thirty-three children in February and thirty-three in June. Two children appeared for both terms, having failed twice. This meant that there were sixty-six cases for the two semesters. The name, chronological age at date of failure and average marks for the term in which he failed were available for each of the sixty-six children. The name of his teacher and of his school headed the promotion sheet. This last information was necessary for consulting other types of records.

Ages of failures. The directors of the recent Louisville Survey seemed to experience the same difficulty as did the writer in establishing a definite age limit for the grade beyond which retardation began. Strayer says that the normal age limit on entering Grade Six is from eleven years three months to twelve years three months. This would put the maximum normal age for leaving the sixth grade at thirteen years three months, since a February class would be leaving a full year after entering.

\footnotetext{
99 Works, op.cit., p.257.
} 
Table IX shows the chronological age spread for the sixty-six children mentioned in the study. The spread extended from eleven years eight months to sixteen years five months. This table shows twenty-six ehildren who were older than Strayer's norm. The median age for the group was twelve years eleven months.

Figure I gives a summary of the chronological ages. It shows plainly that the largest group is within the twelve year limits. The presence of a black of sixteen year olds is a matter to be deplored. Recommendations for this group will be presented later in the study.

Mental ages and intelligence quotients of failures. The lists of achievement and intelligence tests results on file at the Board of Education were next consulted. All children who are members of a $6 \mathrm{~A}$ class are given these tests unless they are absent at the time. It was impossible to find the records for eight of the children on the list. This, of course, meant that they were not present when the test was given--either through non-attendance ot late entry. These were group test results. During the year chosen for this study, the test given was the Kuhlmanf-anderson sixth Grade Test. Some of these children had individual tests but that will be discussed in the next section of this chapter. 
Chronological Age Spread at Date of Failure for 66 Children Who Were Failures in the 6A Grades of the Louisville Public Schools for the Year 1941-42

\section{TABIE IX}

$\begin{array}{llll}\text { Age } & \text { No. of Cases } & \text { Age } & \text { No. of Cases } \\ 11-8 & 2 & 13-4 & 1 \\ 11-9 & 2 & 13-5 & 1 \\ 11-11 & 1 & 13-6 & 1 \\ 12-0 & 2 & 13-7 & 1 \\ 12-1 & 2 & 13-8 & 2 \\ 12-3 & 1 & 13-9 & 1 \\ 12-4 & 3 & 13-10 & 1 \\ 12-5 & 4 & 14-0 & 2 \\ 12-6 & 3 & 14-1 & 2 \\ 12-7 & 3 & 14-2 & 2 \\ 12-8 & 2 & 14-3 & 3 \\ 12-9 & 2 & 14-4 & 3 \\ 12-10 & 3 & 14-5 & 1 \\ 12-11 & 4 & 15-2 & 1 \\ 13-0 & 1 & 15-4 & 1 \\ 13-2 & 4 & 16-0 & 2 \\ 13-3 & 1 & 16-5 & 1\end{array}$

Median Age 12-11 
No. of Cases

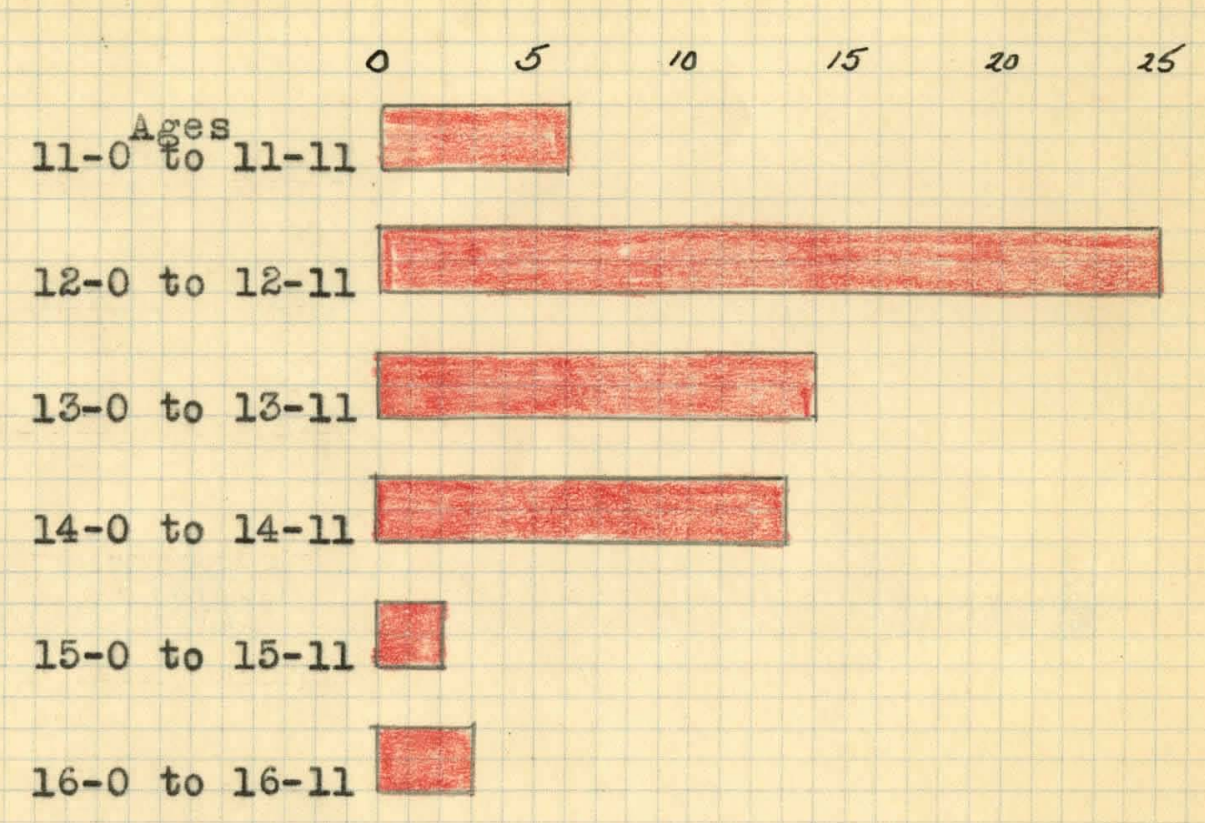

FIGURE I

Age Groups at Date of Failure for Children

Who Were Failures in the $6 \mathrm{~A}$ Grades of Louisville for the Year $1941-42$ 
Table $X$ and Figure 2 show the results of the group intelifigence tests. It will be oberved that the largest number of children fall into the dull normal group with intelligence quotients of 75 to 90 , although there are almost as many in the normal group with 90 or above. In considering the comparatively small number in the mentally $\mathbb{f e f i c i e n t}$ group, it is well to remember that there were, at the time this study was made, slow learning classes in many of the elementary schools, in which would be found many of the children of this group. According to the Works Survey, 100 cent of the children of the elementary grades were in slow learning classes for the year 1942-43, the year following this study. A check of promotion sheets for June, 1942 would seem to show sixteen such classes. There was one class in each of six schools, two schools had three classes each and in one school there were four. It is of importance to discover that 43.1 per cent of these failures tested normal on a group intelligence test. Although any written group inteligence test does not pretend to eliminate ruch factors as emotions and work habits, the score should be a good index to possible academic achievements, a fact which begins to point early in this study to a possible failure on the part of teachers rather than children. 


\section{TABLE $X$}

Spread of Intelligence Quotients of Failures from the 6A Grades of the Louisville Public Schools

$$
\text { for the Year 1941-42 }
$$

Total Number of Failures-66 Number with Recorded Scores-58

\begin{tabular}{|c|c|c|c|c|c|}
\hline \multicolumn{2}{|c|}{$\begin{array}{c}\text { Below } 75 \\
\text { (Mentally deficient) }\end{array}$} & \multicolumn{2}{|c|}{$\begin{array}{c}75-90 \\
\text { (Dull Normal) }\end{array}$} & \multicolumn{2}{|c|}{$\begin{array}{l}\text { Above } 90 \\
\text { (Normal) }\end{array}$} \\
\hline$I . Q$. & $\begin{array}{l}\text { No. of } \\
\text { Cases }\end{array}$ & $I . Q$. & $\begin{array}{l}\text { No. of } \\
\text { Cases }\end{array}$ & $I . Q$. & $\begin{array}{l}\text { No. of } \\
\text { Cases }\end{array}$ \\
\hline 49 & 1 & 77 & 3 & 91 & 1 \\
\hline 59 & 1 & 79 & 2 & 92 & 2 \\
\hline 63 & 1 & 80 & 1 & 93 & 3 \\
\hline 64 & 1 & 81 & 1 & 95 & 1 \\
\hline 69 & 1 & 83 & 5 & 96 & 2 \\
\hline 72 & 1 & 84 & 1 & 97 & 1 \\
\hline & & 85 & 1 & 98 & 1 \\
\hline & & 86 & 1 & 100 & 1 \\
\hline & & 87 & 3 & 101 & 3 \\
\hline & & 88 & 1 & 103 & 1 \\
\hline & & 89 & 3 & 104 & 2 \\
\hline & & 90 & 5 & 106 & 1 \\
\hline & & & & 107 & 3 \\
\hline & & & & 110 & 2 \\
\hline & & & & 114 & 1 \\
\hline Total & 6 & & 27 & & 25 \\
\hline
\end{tabular}


58 Cases

No. of Cases

$\begin{array}{lllllll}0 & 5 & 10 & 15 & 20 & 25 & 30\end{array}$

Below 75
(Mentaliy defioient)

\author{
(Duil to 90 rimal)
}

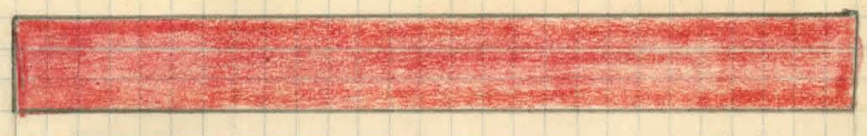

A bove 90
(ivormai)

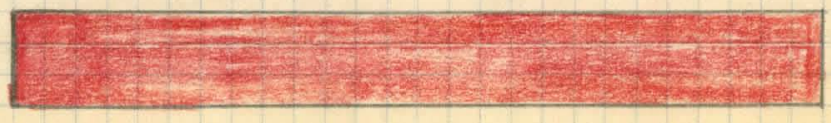

FIGURE 2

Grouping of Intelligent Quotien ts

as shown by Kuhlmann-Anderson Tests

for Failures from the $6 \mathrm{~A}$ Grades of the

Louisville Public Sohools for the Year 1941 - 42 
Bureau of Research Information. The files of the Bureau of Research contained other helpful information besides the results of group tests. In that department are records and in some instances case studies of any children who have had any individual testing since they entered the Louisville School system. Of these 66 failures for the year 1941-42, 16 had some type of testing besides the tests given all the children in the city of their grade testing. In some cases, these were special small group tests at their own schools to determine advancement or placement. Sometimes such tests were recommended by the Bureau of Research but most often they were adrocated by the principal of the school which the child was attending at the time.

Six of these children had individual Binet tests administered at some time in their elementary school life. These were given by a staff psychologist at the Bureau of Research. In some cases, one or more subject matter tests were administered at the same time. In several cases only such matter tests were given. Table XI shows the type of testing given in each of the sixteen cases and in what grades such tests were administered.

These figures showed that in 24.2 per cent of the 64 children who failed, some type of special testing was given to supplement the routine testing of all the children. A 
program in which all children were given special tests before. failure would be final. It would, however, entail a larger testing staff than that now employed by the Louisville Board of Rucation.

Number of boys and girls. Many of the failure studies quoted in the early chapters of this study stressed the fact that more boys than girls fail. The numbers were close in the group studied here. of the sixty-four children, thirtyfour were boys and thirty girls.

Table XII shows that this same ratio has seemed to persist for the last five years and that a grand average gives the girls a promotion record higher by only ninetenths of a per cent. However, when we read a list of failures by studies and grades for the Louisville schools, as in Table XIII, we find a different story. Here the boys skow a much larger number of failures. This record, however, is not completely authentic, since it allows for a wide variation in what the individual teacher counts as failure in a subject.

With an interpretation of failure as meaning nonpromotion, we find that in the $6 \mathrm{~A}$ grades of the Louisville schools, there seems to be a slightly higher percentage of boys failed than girls, but that the variation is small. 
Types of Tests Given Failures from the 6A Grades for the Year 1941-42 Who Were Given Special Tests During Their Membership in The Louisville Public Schools

\begin{tabular}{|c|c|c|}
\hline Cases & $\begin{array}{l}\text { Grade when } \\
\text { Tested }\end{array}$ & Type of Test \\
\hline A & $\begin{array}{l}5 \mathrm{~A} \\
6 \mathrm{~A}\end{array}$ & $\begin{array}{l}\text { Intelligence (Binet), Achievement } \\
\text { Intelligence (Group), Schievement } \\
\text { (Also recommended in } 1938 \text { to Mental Hygiene } \\
\text { clinic) }\end{array}$ \\
\hline $\bar{B}$ & IA & $\begin{array}{l}\text { Special Tests at own school, Intelligence, } \\
\text { Reading }\end{array}$ \\
\hline C & $4 \mathrm{~A}$ & Intelligence \\
\hline$\overline{\mathrm{D}}$ & $3 \mathrm{~A}$ & Intelligence, Reading, Arithmetic \\
\hline $\mathbf{E}$ & $5 \mathrm{~B}$ & Intelligence \\
\hline $\bar{F}$ & Ungraded & 1936 Intelligence, Reading \\
\hline $\bar{G}$ & $6 \mathrm{~A}$ & Achievement \\
\hline$\overline{\mathrm{H}}$ & IB & Intelingence \\
\hline $\bar{I}$ & $\frac{1 \mathrm{~A}}{6 \mathrm{~A}}$ & $\begin{array}{l}\text { Intelligence } \\
\text { Intelligence }\end{array}$ \\
\hline $\mathrm{J}$ & Ungraded & (Binet), Reading \\
\hline$\overline{\mathrm{K}}$ & $1 \mathrm{~A}$ & Intelligence \\
\hline $\mathrm{I}$ & $6 \mathrm{~A}$ & Intelligence (Binet) \\
\hline$\overline{\mathrm{M}}$ & $4 \bar{B}$ & Intelligence (Binet) \\
\hline $\mathrm{N}$ & $5 \bar{B}$ & Intelligence, Reading, Arithmetic \\
\hline$\overline{0}$ & $6 \mathrm{~A}$ & $\begin{array}{l}\text { General Achievement - Special Testing } \\
\text { in small group at own school }\end{array}$ \\
\hline $\bar{P}$ & 5B & $\begin{array}{c}\text { Intelligence, Arithmetic, Reading - Special } \\
\text { testing in small group at own school }\end{array}$ \\
\hline
\end{tabular}




\section{TABLE XII}

Promotion Percentages for Children of the 6A Grades of the Louisville Public Schools for Five School 101

Years 1937-38 through 1941-42

\begin{tabular}{llllllll}
\hline & \multicolumn{3}{c}{ January } & \multicolumn{3}{c}{ June } \\
& Boys & Girls & Total Boys & Girls & Total \\
\hline $1937-38$ & 99.0 & 98.9 & 99.0 & 97.9 & 98.7 & 98.3 \\
$1938-39$ & 97.4 & 99.0 & 98.2 & 95.5 & 98.2 & 96.8 \\
$1939-40$ & 95.9 & 97.5 & 96.7 & 96.3 & 97.7 & 97.0 \\
$1940-41$ & 97.5 & 97.6 & 97.6 & 96.6 & 97.3 & 96.9 \\
$1941-42$ & 96.8 & 96.5 & 96.7 & 97.7 & 98.2 & 97.9 \\
& & & & & & \\
Average & 97.3 & 97.9 & 97.6 & 96.8 & 98.0 & 97.4
\end{tabular}

Grand Average

Jan. - June 97.198 .0

I0I

Twenty-serenth Report of the Board of Education of Louisville, Kentucky, pp.39,40.

Twenty-eight Report

Twenty-ninth Report

Thirtieth Report

Thirtt-first Report

$$
\begin{aligned}
& \text { pp. } 35,36 . \\
& \text { pp. } 23,24 . \\
& \text { pp. } 57,58 . \\
& \text { pp. } 31,32 .
\end{aligned}
$$


Numbers of 6A Pupils Who Were Subject Failures

$$
\text { for June } 1942
$$

Showing Percentage of Boys and Girls Separately

\begin{tabular}{lccccc}
\hline & \multicolumn{3}{c}{$\begin{array}{l}\text { Boys } \\
\text { No. Per cents }\end{array}$} & \multicolumn{3}{c}{ No. Per cents } & Total \\
\cline { 2 - 5 } Reading & 86 & 62.8 & 51 & 37.2 & 137 \\
Spelling & 85 & 69.7 & 37 & 30.3 & 122 \\
Language & 111 & 68.9 & 50 & 31.1 & 161 \\
Arithmetic & 118 & 55.9 & 93 & 44.1 & 211 \\
History & 91 & 58.0 & 66 & 42.0 & 157 \\
Geography & 74 & 56.5 & 57 & 43.5 & 131 \\
Other Subjects & 123 & 69.1 & 55 & 30.9 & 178
\end{tabular}

102

Twenty-seventh Report of the Board of Education, Louisville, Kentucky, pp. 4l,42. Twenty-eighth Report

Twenty-ninth Report

Thirtieth Report

pp. $37,38$.

Thirty-first Report pp. 25,26. pp. 59,60 pp. 33,34. 
Summary of status of failures used in this study. To summarize, then, this study shows 66 failures in the $6 \mathrm{~A}$ grades of the Louisville schools for the year 1941-42. Among these, two names appear twice. These children range in age at time of failure from eleven years eight months to sixteen years five months, with a median age of twelve years eleven months. Their intelligence quotients range from 49 to 114, with a median intelligence quotient of 90 . of the 64 different children mentioned in the study, 16 have had some special type of testing by the Bureau of - Research during their school lives. Of the 64 children, 34 were boys and thirty girls. 
CHAPTER V

CAUSES OF FAILURE 


\section{CHAPTER $V$}

\section{CAUSES OF FAILURE}

The causes of a child's failure to be promoted might be determined in many ways. Some of the studiese quoted show what pupils, parents, teachers, or administrators felt were the reasons for failure. The causes in thiscotudy were derived by studying the questionnaire results, checking the attend nce of the child as recorded on the ppomotion sheet, studying the teachers' marks on the same record and noting the standing of the child on the achierement tests given early in the semester on which he failed.

Questionnaire results. In 1943 one or more copies of the questionnaire, Table XIV were sent to each teacher who had recorded failures on her promotion sheet for the preceding year, 1941-42. Answers were received from all but four teachers. There was a total of seven failures recorded on the promotion sheets of these four. This meant that there was some type of questionnaire information for 59 cases.

Tables XIV and XV show a tabulation of the causes checked by the teachers. Often, of course, several different reasons were checked on the same questionnaire. Poor attendance leads. Thirty-two cases had poor attendance checked as at least a contributing cause of failure. Table XVI shows the varying attendance records of these 65 children, there being one case in which attendance was not recorded. To surnarize, 


\section{TABLE XIV}

Results from the Questionnaire sent to the

Teachers of 6A Failures for the Year 1941-42

Please check the following information for

who was a failure in the $6 \mathrm{~A}$ grade of your school in

I. Causes of failure (check one or more)

A. Poor home conditions 24

1. Eyes $\frac{5}{5}$

2. Ears $\frac{5}{5}$

3. Others 5 (note type)

C. Poor health ${ }^{-}$(note any chronis illness)

D. Limited use of English language due to use of foreign language at home 0

E. Mental incapacity $\overline{30}$

(check authority for statement)

1. Teacher's judgment 14

2. Group test 20

3. Individual test, Bureau of Research 10

F. Immaturity 12

G. Prequent transfers 6

H. Late entrance 13

1. From another school in Louisville 2

2. From a school in another city 3

3. From a rural school 4

4. From a parochial school 3

5. From a private school

I. Unwise previous promotion 18

$J$. Poor attendance 32

1. Due to iliness I3

2. Due to truancy $\frac{1}{8}$

3. Due to lack of clothing 5

4. Due to other reasons (note these) 9

$K$. Lack of interest and effort 21

L. Misbehavior 16

1. Inattention 13

2. Anti-social behavior, fighting, etc., 4

3. Insubordination 1

4. Others (note types) 1

M. Other reasons (note) 3

II Special help given child previous to failurelcheck no or

A. Outside tutoring 0

B. Coach class 13

C. Extra help by teacher 35

D. Special tests and recommendations by Bureau of Research 3

E. Case study by visiting teacher 13 
TABLE XIV (continued)

III. Which of these did you notice the term after the child failed?

A. Child showed improvement in work 27

B. Showed no improvement in work 9

C. Gained in assurance 23

D. Became mature enough for group he entered 5

F. Acquired hostile attitude toward school and teacher 1

F. Became more of an attendance problem 9

G. Showed greater interest and effort $2 \overline{0}$

H. Showed less interest and effort 5

I. Improved in social behavior 3

$\mathrm{J}$. Became more antagonistic to other children 2 
Reasons Ascribed by Their Teachers for Failures of Children Not Promoted in the 6A Grades of Louisville for the year 1941-42 Arranged According to Number of Checks on the Questionnaires

\begin{tabular}{|c|c|c|}
\hline Reasons & $\begin{array}{c}\text { Number } \\
\text { of cases } \\
\end{array}$ & $\begin{array}{l}\text { Per cent } \\
\text { of Total }\end{array}$ \\
\hline Poor attendance & 32 & 16.7 \\
\hline Mental incapacity & 30 & 15.7 \\
\hline Poor home conditions & 24 & 12.6 \\
\hline Lack of interest and effort & 21 & 11.0 \\
\hline Unwise previous promotion & 18 & 9.4 \\
\hline Misbehavior & 16 & 8.4 \\
\hline Late entrance & 12 & 6.3 \\
\hline Immaterity & 11 & 5.8 \\
\hline Poor health & 11 & 5.8 \\
\hline Physical defects & 8 & 4.2 \\
\hline Frequent transfer & 6 & 3.1 \\
\hline Other reasons & 2 & 1.0 \\
\hline Limited use of English in home & 0 & 0 \\
\hline Total & 191 & 100.0 \\
\hline
\end{tabular}




\title{
TABLE XVI
}

\begin{abstract}
Attendance Record Showing Number of $6 \mathrm{~A}$ Failures for the Year 1941-42

Who Had Various Attendance Percentages
\end{abstract}

\begin{tabular}{|c|c|c|c|}
\hline $\begin{array}{l}\text { Attendance } \\
\text { Percentages }\end{array}$ & No. of Cases & $\begin{array}{l}\text { Attendance } \\
\text { Percentages }\end{array}$ & No. of Cases \\
\hline 100 & 3 & 78 & 2 \\
\hline 99 & 1 & 77 & 1 \\
\hline 98 & 1 & 76 & 3 \\
\hline 97 & 1 & 72 & 1 \\
\hline 96 & 5 & 70 & 2 \\
\hline 95 & 2 & 69 & 2 \\
\hline 94 & 3 & 67 & 1 \\
\hline 93 & 1 & 66 & 3 \\
\hline 92 & 3 & 64 & 1 \\
\hline 91 & 1 & 63 & $I$ \\
\hline 90 & $I$ & 59 & 1 \\
\hline 89 & 3 & 55 & 1 \\
\hline 88 & 1 & 54 & 1 \\
\hline 87 & 2 & 47 & 1 \\
\hline 83 & 3 & 43 & 1 \\
\hline 82 & 2 & 38 & 1 \\
\hline 81 & 1 & 37 & 1 \\
\hline \multirow[t]{3}{*}{80} & 4 & 36 & 1 \\
\hline & & 28 & 1 \\
\hline & & 25 & 1 \\
\hline
\end{tabular}


there were three with 100 per cent attendance, 19 with from 90 to 99 per cent, 16 with from 80 to 89,9 with from 70 to 79,8 with from 60 to 69 , and 3 with from 50 to 59 per cent attendance. There were 7 children whose attendance records fell below 50 per cent.

There seems to be no definite statement any where in educational literature as to an exact point below which attendance becomes poor attendance. Of course, the ability and willingness of the child to make up the work he has missed would be closely interlinked factor here. Perhaps the ability and willingness of the teacher to help him to do so would be even more important.

However, it was evident, when attendance records as found on promotion sheets were checked against the questionnaire results that there was a disagreement among the teachers involved so to what constituted poor attendance. of course, the teachers may have checked only chief causes and felt in some cases that the other causes were more important then poor attendance.

In studying the percentages and the questionnaire results it appeared that three teachers checked the attendance as poor for children who had attended over 90 per cent of the term in which they failed. These three children missed the following number of days: (a) 9 out of a 96 ter day term, (b) 8 out of a 96 day term and (c) 7 out of a 82 day term. These three 
cases certainly seemed to show an error in judgment on the teacher's part.

For the 13 children in the 80 to 89 per cent range who had questionnaires checked for them the records of 5 showed the teacher considered this attendance as poor, of the 9 in the 70 to 79 per cent group all were considered by their teachers to have poor áttendance as a contributing factor of failure. In the 60 to 69 per cent group 7 of the 8 were so considered and in the 50 to 59 per cent group on $7 y 1$ of the 3. Of the 7 below 50 per cent all had poor attendance checked on heir questionnaires.

Tabel XIV showes illness as the greatest reason for poor attendance. The questionnaire gave no opportunity for noting the type of illness. In many cases, of course, a child is able to do work at home if it is provided. Two examples which have recently come to the writer's notice are these. A child was injured in an automobile accident. He had both left leg and left arm in plaster casts. It was necessary for him to remain at home six weeks. He was in bed during that time. After the shock of the accident was over he was eager to begin school work and his parents were also eager for him to do so. With an occasional few minutes spent by his teacher in checking his work he was able to go on with his class when he returned.

A child excluded from school because of mumpsasked for work. 
Since health officers agree that mumps cannot be carried by papers, work was sent to him to be returned by him to the teacher when he was well. In this way the days of his quarantine were spent profitably.

In cases where the child returns in a physical condition to warrant it, carefully planned work can be given him which will enable him to meet the requirements of his grade or his ability. Some schools prefer the time before school, and some after school for such makeup tests and extra help. A coaching teacher in each school for such help would be ideal but probably impossible with the present funds available to the Board of Education.

The next largest number checked "other reasons". Some of these listed are: accident, indifference, indifference on part of parents, help at home, work, inclement weather, leaving city to visit relatives.

Eight checked truancy as a cause of poor attendance. The indifference mentioned in the forgoing paragraph might perhaps be counted with these eight cases. They both might well be considered effects of failure as well as causes but that will be treated at greater length later.

Five found lack of clothing the reason for non-attendance. The visiting teacher in each school usually checks on 
the validity of such statements and in most cases clothes can be provided by either visiting teacher or principal from stocks built up by gifts of used clothes from parent-teacher associations of the city.

In many cases teachers check non-attendance as an impor103

tant reason for failure. Ayres at an early date, found it given frequently. Adams found it stated as second in importance by the teachers he questioned. Many educators, however, feel that poor attendance is much more apt to be reckoned a result of failure and its consequent emotional upsets than a cause. The truancy and indifference checked in these questionnaires could be certainly due, at least in part, to the child's feeling of imcompetency. Many of these children are overage for their grades--a fact which proves in most cases a record of failure.

Non-attendance, then, by itself, can hardly be considered a fair cause for failure unless it is thought of in connection with and dependent upon other fators.

For 30 children the teachers checked mental incapacity as a cause of failure. Table $X$ in Chapter IV of this study showed that only 6 were really mentally deficient but that 27 children were in the dull-normal group according to the results of the Kuhlman-Anderson Intelligence Tests.

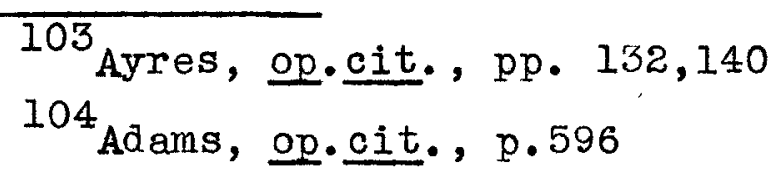


According to the questionnaires 20 cases were judged mentally incapable because of group test results and 10 because of individual test results. Investigation at the Bureau of Research showed that Binet tests were given to 6 of these children at some time in heir school lives. Fourteen cases were judged mentally incapable according to teacher judgment. In some of these cases the teacher had checked that she had used some type of test to help her decision.

The intelligence rating of the group of children on whose questionnaires mental incapacity was checked was next investigated. The results are shown on Tabe XVII. Three children were found an I.Q. below 75 and according to this test mentally deficient. Eighteen ranged from 75 to 90 which put themin the dull-normal group. Four were above 90 so could not be considered in any way mentally ineapable if the test results were correct.

Twenty-four teachers checked poor home conditions. There is no way of knowing whether these conditions had been investigated by the classroom teacher or the visiting teacher. The services of the latter are always avallable in the Louisville schools.

Twenty-one checked lack of interest and effort on the part of the child. This is always a debatable factor. In many cases the lack of interest and effort is on the part of 
the teacher. Wight of the children checked were over fourteen years old and three were almost fourteen. The fact that they were still in a school situation set up for twelve year olds would certainly cause indifference on their part.

Unwise previous promotion was given as a reason for failure in eighteen cases. This is, of course, a purely subjective reason. It sets up immediately the theory that promotion should be based on the reaching of certain academic goals regardess of the ability of the child.

Sixteen listed behavior as a cause of failure. of these 13 cases of inattention were recorded: Here again it is hard to interpret without knowing the reasons behind the inattention. No child in this group had physical defects which might lead to his inattention. Two had I.Q.'s above 100, and 2 others were over 90. One was 90 , one 89 , one 83 , two 87, and one 86. One dropped to 79 and one to 59. For the most part, however, they appeared to have enough intelligence according to the group test to show interest in work geared to their ability.

only four teachers listed anti-social behavior as a cause for non-promotion. There can, of course, be no real connection between this and failure to be promoted uhless such behavior prevented academic achievement. No child could ever fairly be failed because of this type of misbehavior. 
STANDING ON KUHEMTANN-ANDERSON TEST OF 6A FAILURES FOR THE YEAR 1941-42 SHECKED MENTALLY INCARABLE ON THE QUESTIONNAIRES SENT IN BY THEIR TEACHERS (4 unrecorded)

\begin{tabular}{|c|c|c|c|c|c|}
\hline \multicolumn{2}{|c|}{$\begin{array}{l}\text { (Mentally deficient) } \\
\text { Scores below } 75\end{array}$} & \multicolumn{2}{|c|}{$\begin{array}{l}\text { (Dull Normal) } \\
\text { Scores from } 75 \text { to } 90\end{array}$} & \multicolumn{2}{|c|}{$\begin{array}{c}\text { (Normal) } \\
\text { Scores above } 90\end{array}$} \\
\hline Score & $\begin{array}{l}\text { No. of } \\
\text { Cases }\end{array}$ & Score & $\begin{array}{l}\text { No. of } \\
\text { Cases }\end{array}$ & Score & $\begin{array}{l}\text { No. of } \\
\text { Cases }\end{array}$ \\
\hline 59 & 1 & 77 & 2 & 92 & 1 \\
\hline 63 & 1 & 79 & 1 & 98 & 1 \\
\hline 64 & 1 & 80 & 1 & 101 & 2 \\
\hline \multirow[t]{7}{*}{69} & 1 & 81 & 1 & & \\
\hline & & 83 & 3 & & \\
\hline & & 86 & 1 & & \\
\hline & & 87 & 3 & & \\
\hline & & 88 & 1 & & \\
\hline & & 89 & 3 & & \\
\hline & & 90 & 2 & & \\
\hline
\end{tabular}


One listed insubordination. This could easily mean that no work at all was done. Showing off as a compensation for small stature was another form of misbehavior checked on one paper. This could interfere with child's work but otherwise could not fairly be held as a reason for failure.

There were 12 questionnaires that showed late entrance as a cause. Three of these children had entered from rural schools, 3 from city schools outside of Louisville, three from Louisville parochial schools and 2 from public schools in Louisville. One teacher did not specify the type of school. The two teachers who felt that late entrance from another public school in Louisville was a reason for failure demonstrated either a lack of unity in promotion standards in Louisville or else a lack of achievement standards and methods used to reach them. However, it is undoubtedly true that there is in many cases a refusal to accept the standards set by another school either in the same city or in a different city. The great harm which may be done the child by refusing to accept the grade placement of the school from which he came is overlooked in the desire to keep the achievement standards of the receiving school high.

of the 7 children marked as enrolling late in the first semester of 89 days, 3 showed as enrollment of the complete 89 days on the promotion sheet; so the late enrollment must have occurred the term before. One showed 64 days, one 46 , 
one 46, and one 13. This last child seemed to have been with the teacher long enough for her to ascertain that he needed to know more fractions and decimals before he went to junior high school since he did not learn enough of these in the city from which he came.

The second semester lasted 96 days. One child was enrolled for the entire 96 days according to his promotion sheet. One was enrolled for 76 days, one for 47 days, one for 45 and one for 40 .

Late entrance as a cause for failure certainly seems to penalize the child for something over which he could have no control. Surely the teacher in the next grade could offer help in the subjects which the sending school seemed to have neglected. It is possible that they may have done better than the receiving school with certain other subjects.

It was interesting to consider the ages of the children marked failures because of immaturity. Their ages in years and months were as shown in Table XVII.

Two children were below 12 years of age. Seven were within the 12 year limits. One child was 13 and one 14. There are, of course, many kinds of immaturity. Chronological age does not necessarily bring with it physical, mental or emotional maturity but surely a 13 or 14 year old child should not sit in $6 \mathrm{~A}$ class waiting to become more mature. 


\section{TABLE XVIII}

Chronological Ages of 6A Failures for the

Year 1941-42 Who Were Marked on Questionnaires

as Failures Because of Immaturity

Chronological Age No. of Cases

$\begin{array}{ll}11-8 & 1 \\ 11-9 & 1 \\ 12-3 & 1 \\ 12-5 & 2 \\ 12-6 & 1 \\ 12-10 & 1 \\ 12-11 & 2 \\ 13-6 & 1 \\ 14-1 & 1\end{array}$


There were 11 cases of poor health. In 5 of these cases, teachers failed to specify the type of difficulty. Two mentioned frequent colds. One said the child appeared to be undernourished, and one that the child in question was frail and ate poorly. In this case the teacher noted that the mother was in a tuberculosis sanitarium. Two mentioned an apparent nervous condition and of these said the child cried easily. These last aamed cases could be, again, effects of failure as well as causes.

The Louisville schools have bee able to enlist the aid of the Louisville Board of Health in seeing that occasional physical examinations are made, and in giving special examinations and home visits where this seems advisable. The nurses and doctors who work under this board have helped in many cases to eliminate poor health as a cause for failure.

For eight children chances of promotion seemed to be ruined by physical defects. Two of these had ear defects. Thre had visual defects. The teacher of one of these three noted that she tried for a year to get the mother to buy glasses for the child. One child had a speech defect which resulted in a hesitancy of speech. One had bad tonsils as well as bad ears and one had defective eyes and ears. Here again the nurses and doctors from the Board of 
Health in cooperation with the health supervisor of the Louisville public schools have set up a system of eye and ear examinations which should catch most of the worst cases of visual and auditory difficulty. There are special classes in the Louisville schools for the worst cases. The most difficult problem, perhaps, is to persuade parents to provide corrective treatment either through clinics or private physicians.

Six teachers mentioned frequent transfer as a vause of failure. Four of these cases were also checked for late entry although one of these four showed a complete enrillment on the promotion sheet. A complete record of the child's school experience would be netessary before judgment could be passed on this as a factor in failure.

"Other reasons" was checked on two copies of the questionnaire. Both reasons given here could, however, have appeared under other headings. "Daydreamer" should have come as a type of misbehavior, perhaps. The second teacher to check this place said that the child was poorly prepared, having come from out of the city. This could, perhaps, have been noted under late entry although he was enrolled in this Louisville school for the entire semester in which he failed.

The teachers of the $5 \theta$ children for whom questionnaires were returned put poor attendance and mental incapacity above 
other causes for failure. Poor home conditions and lack of interest and effort came next. Unwise previous promotion showed two more checks than misbehavior. Late entrance came next with immaturity and poor health just below this. Physical defects and frequent transfer ended the list except for two other reasons which were specifically noted--namely daydreaming and insufficient preparation. No teacher checked a limited use of English in the home although one in another conncection mentioned the mother's difficulties with the language.

Teachers: marks. Most teachers would sunscribe to the theory that their promotions are largely based on the academic achievement of the children in their classes. This achievement is marked by the teacher and such marks appear on a record sheet kept by the teacher and on a report sent to the parents. The average mark for each subject for each semester is recorded on promotion sheets, one copy of which is retained by the principal and one sent to the central office. The sheets were studied to obtain the information used here.

The elementary school children in the Louisville schools are given marks of 1,2 and 3 . These stand for above average, average and below average work. Besides this, they are marked $U$ in any unsatisfactory habits, but those marks are not to be considered at this point. 
of the 66 children used in this study, 4 had no marks on the promotion sheets for their grades. For 3 of these the reason was non-attendance. One marked "mentally deficient" in the place for grades.

of the remaining 62,43 showed a 3 average which meant that the teacher had actually graded them below average for their group. Sixteen had a 2 average. This meant that they had been marked as doing average work for the term in which they failed. Of these 16, II had a 2 average in the important academic subjects--reading, arithmetic, language, spelling, history and geography. If they were average for their group why were they not promoted? The entire group was not failed. one child had a 1 average. This certainly cannot be explained. Why would a child whom the teacher herself considered above average in achievement be failed?

Table XIX shows the achievement of the 62 children who had averages on the promotion sheets in the more important academic subjects. It will be noted that the averages were about the same in all subjects except spelling. Ability in spelling and in reading have a very high correlation but this would not seem to be true here.

\footnotetext{
105

Ernest Horn, "Speling", Encyclopedia of Educational Research, 1941. Edition, p.1177.
} 
Achievement test results. As before stated all these children had a standard achievement test after they had been in the $6 \mathrm{~A}$ about one month. The test given was the Progressive Achievement. This test was given, of course, four months before the date at which the child failed, but since average accomplishment during that time would be four months the grading would still be close enough to be applicable.

There was a wide range of achievement totals for the group. This was as follows:

$\begin{array}{llll}7 B-1 & 5 A-7 & 4 B-6 & 2 A-1 \\ 6 A-1 & 5 B-11 & 3 A-2 & 2 B-1 \\ 6 B-7 & 4 A-9 & 3 B-0 & 1 A-1 \\ & & & 1 B-0\end{array}$

This shows that only one child was above the achievement for the grade and only one was at the $6 \mathrm{~A}$ level.

Total achievement does not, of course, tell the entire story. In several cases where the child showed fifth or sixth grade achievement for his total he showed seventh ot eighth grade achievement in certain subjects. This always makes it appear possible that with special help in the low subjects the child sould even his achievement and make failure unnecessary.

Eighteen children did not take the test. of those, 6 were late entries which probably means that they were not members of the group at the time the test was given. The other 
8 must have been absent at the time of the test. In several cases this was recorded on the test sheet. Tests for absent children always mean extra work for the teacher but since the test material was available it would probably have been wise to test these children before failing them. Is this was done the results were not recorded at the Board of Education. Two of the children who were not tested because of late entrance were given special tests later, one at his school and the other at the Board of Education.

It is, of course, true that in some classes no child would reach $6 \mathrm{~A}$ standard on such tests. Therefore it seemed wise to consider the standing of the child within his group. Tabel XX shows 12 cases in which one-third of the class was on the same level or below these children in total achievement. Unless children on the basis of achievement alone. In cases $A$ and $B$ the children appeared to stand practically at the top of their classes. It is possible that by the end of the term they were excelled by others in the group.

Considering the entire group who showed recorded totals on promotion sheets, 7 children were at the bottom of their class lists in achievement with no child on their level or below. In 8 cases, from 1 to 9 per cent of the class was on a par or below; 7 cases, 10 to 19 per cent, in 9 cases, 20 to 29 per cent, in 4 cases 30 to 39 per cent; in one case 40 to 


\section{TABLE XIX}

Marks Assigned by Teachers to 62 of the Children who Were Failures in the 6A Grades for the Year 1941-42

\begin{tabular}{|c|c|c|c|}
\hline Subjects & $\begin{array}{c}\text { Teachers' } \\
1 \\
\end{array}$ & $\begin{array}{c}\text { Marks } \\
2 \\
\end{array}$ & $\left(\begin{array}{c}3 \\
3\end{array}\right.$ \\
\hline Reading & 2 & 11 & 49 \\
\hline Arithmetic & 0 & 10 & 52 \\
\hline Spelling & 3 & 24 & 35 \\
\hline Language & 1 & 9 & 52 \\
\hline *Geography & 0 & 10 & 51 \\
\hline *History & 1 & 8 & 52 \\
\hline
\end{tabular}




\section{TABLE XX}

A Study of Twelve of the 6A Failures for the Year 1941-42 and Their Standing Within Their Own Class Group According to Scores Made on the Progressive Achievement Tests With Percentages Showing the Ratio of Children in Each Class Who Made Similar or Lower Scores on These Tests

\begin{tabular}{|c|c|c|c|c|c|c|}
\hline Case & $\begin{array}{c}\text { Total } \\
\text { Ach. }\end{array}$ & $\begin{array}{l}\text { adin } \\
\text { Voc. }\end{array}$ & $\begin{array}{l}\text { Readin } \\
\text { comp. }\end{array}$ & $\begin{array}{c}\text { Arithmetic } \\
\text { Reas. }\end{array}$ & $\begin{array}{c}\text { Arithmetic } \\
\text { Fund. }\end{array}$ & Language \\
\hline A & $97 \%$ & $94 \%$ & $92 \%$ & $97 \%$ & $97 \%$ & $94 \%$ \\
\hline$B$ & $97 \%$ & $94 \%$ & $97 \%$ & $83 \%$ & $89 \%$ & $94 \%$ \\
\hline $\mathrm{C}$ & $73 \%$ & $72 \%$ & $40 \%$ & $86 \%$ & $45 \%$ & $81 \%$ \\
\hline$D$ & \multicolumn{2}{|c|}{$662 / 3 \% 29 \%$} & $59 \%$ & $662 / 3 \%$ & $89 \%$ & $41 \%$ \\
\hline $\mathbf{E}$ & $61 \%$ & $46 \%$ & $54 \%$ & $61 \%$ & $54 \%$ & $69 \%$ \\
\hline $\mathrm{F}$ & $52 \frac{1}{2} \%$ & $52 \frac{1}{2} \%$ & $60 \%$ & $42 \frac{1}{2} \%$ & $15 \%$ & $55 \%$ \\
\hline$G$ & $51 \%$ & $71 \%$ & $51 \%$ & $68 \%$ & $80 \%$ & $34 \%$ \\
\hline $\mathrm{H}$ & $51 \%$ & $71 \%$ & $51 \%$ & $68 \%$ & $22 \%$ & $34 \%$ \\
\hline$I$ & $45 \%$ & $32 \%$ & $42 \%$ & $48 \%$ & $68 \%$ & $19 \%$ \\
\hline$J$ & $38 \%$ & $77 \%$ & $61 \%$ & $77 \%$ & $7 \%$ & $38 \%$ \\
\hline $\mathrm{K}$ & $38 \%$ & $76 \%$ & $35 \%$ & $21 \%$ & $0 \%$ & $82 \%$ \\
\hline I & $37 \frac{1}{2} \%$ & $31 \%$ & $6 \frac{1}{4} \%$ & $75 \%$ & $50 \%$ & $62 \frac{1}{2} \%$ \\
\hline
\end{tabular}


49 per cent; in 3 cases, 50 to 59 per cent; in 2 cases, 60 to 69 per cent; in 8 cases 70 to 79 per cent; and in 2 cases 90 to 100 per cent.

It was also valuable to compare achievement on the standard test with teachers' marks. It must, of course, be noted again that the teachers' marks were recorded at the end of the semester and the achievement test given at the beginning. However the norm for the child would be advanced four months by the end of the semester and that fact would mean that this comparison was more than fair.

It is alittle difficult to compare teachers' marks because of the type of marking used in the Louisville schools. Withethe avarage, above average and below average grading system a child who is 3 in one $6 \mathrm{~A}$ might be 1 in another, depending on the achievement and ability of his group.

There were a few cases, however, in which the achievement acore in reading or arithmetic seemed high for a child graded 3 in these subjects. These cases are shown in Table XXI.

For the most part, however, the achievement tests showed below average results and the teachers' marks were also 3 which signifies below average work. There were no cases in which the teachers' marks were higher than the schievement test results would justify. In other words if promotion is based on achievement alone the test results would show that non-promotion was acceptable in most of these cases. 


\section{TABLE XXI}

Comparison of Teachers' Grades and Achievement Test

Results for Five of the 6A Failures for the Year 1941-42

Whose Achievement Did Not Seem as Low

as Teachers' Grades Would Indicate

\begin{tabular}{ccccccc}
\hline Cases & $\begin{array}{c}\text { Reading } \\
\text { Teachers } \\
\text { Grade }\end{array}$ & $\begin{array}{l}\text { Achv } \\
\text { Test } \\
\text { Result }\end{array}$ & $\begin{array}{c}\text { Arithmetic } \\
\text { Teachers } \\
\text { Grade }\end{array}$ & $\begin{array}{c}\text { Achv. } \\
\text { Test } \\
\text { Result }\end{array}$ & $\begin{array}{c}\text { Total } \\
\text { Teachers' } \\
\text { Grade }\end{array}$ & $\begin{array}{c}\text { Achv. } \\
\text { Test } \\
\text { Result }\end{array}$ \\
\hline A & 3 & $6 \mathrm{~B}$ & 3 & $6 \mathrm{~B}$ & 3 & $6 \mathrm{~B}$ \\
B & 3 & $6 \mathrm{~A}-7 \mathrm{~B}$ & 3 & $5 \mathrm{~A}$ & 3 & $6 \mathrm{~B}$ \\
C & 1 & $9 \mathrm{~A}$ & 2 & $6 \mathrm{~B}$ & 2 & $7 \mathrm{~B}$ \\
D & 2 & $7 \mathrm{~B}$ & 2 & $6 \mathrm{~B}-6 \mathrm{~A}$ & 2 & $6 \mathrm{~B}$ \\
F & 3 & $4 \mathrm{~A}-6 \mathrm{~B}$ & 3 & $6 \mathrm{~B}$ & 3 & $5 \mathrm{~A}$
\end{tabular}


Sumary of the causes of failure. There is little doubt than that with few exceptions the children in this list of failures is achieving below the average for the $6 \mathrm{~A}$ grade according to standard tests and according to teachers' judgement. Their teachers believed that the reasons for their low achievement were as follows: poor attendance, mental incapacity, poor home conditions, lack of interest and effort, unwise previous promotion. misbehavior, late entrance, immaturity, poor health, physical defects and frequent transfer.

The degree of poor attendance was not always borne out by actusal count of days absent. Some of the reasons given for poor attendance seemed to point to the fact that this cause of failure might also be a result.

The low mental capacity of this group as a whole seemed to be a fact as far as group and individual tests of intelligence can be trusted. Poor home conditions as a cause rests entirely on teacher judgment. Lack of interest and effort is much more apt to be a result than a cause of non-promotion. In a number of cases of late entrance or immaturity the facts did not prove that this had been a true cause of the child's failure. No facts could be obtained on the alledged unwise previous promotion.

The few cases of ill health mentioned were given in detail 
so they seemed justified. This was also true of physical defects. Frequent transfer was suggested by the small number of days the child had spent in the room of the teacher responding.

The main thing to be gained in considering these causes was a knowledge of the necessity to look beyond such reemingly fixed reasons to gain, if possible, an understanding of the causes behind these reasons. 
CHAPTER VI

HELP GIVEN BEFORE FAILURE 


\section{HELP GIVEN BEFORE FAILURE}

It is natural to ask when a child is failed what help was given him before failure, and what steps were taken to prevent his becoming a failure. Such action may be taken by the classroom teacher or by the principal of the school. Either of these authorities may call in coaching teachers in the school, the visiting teacher at the school, specialists at the Board of Education or outside coaching help. For the latter the parent pays, of course, and such recourse should probably be a last resort. Where the parent is able to pay for it, however, he will usually be willing to do so in preference to having his child face failure. He will, perhaps, wish to make sure that the need for outside tutoring comes as a result of events over which the school has no control, and not as a result of the school's negligence.

To obtain the information as to what had been done to prevent failure in the 66 cases used in this study, the questionnaires sent ti their teachers were again consulted. Besides this, the files of the Bureau of Research were carefullt investigated. It was found that some help was given in many of the cases. 
Questionnaire results. One section of the questionnaire asked the teacher to check the help given the child before failure. These questionnaires were received for 59 of the 66 failures.

They show that 34 children received extra help from the teacher before failure. The type of help was not listed. This might have taken the form of extra work before or after school or extra homework assignments. Workbooks are often used for this type of remedial work and many excellent ones are now on the market. Some of them are diagnostic as well as remedial.

Thirteen children were in coach classes. In some schools a special teacher has charge of such a class and in others the kindergarten or first grade teachers whose classes are dismissed early do extra coaching in the last hour of the day.

Case studies for 10 of these children were made by the visiting teacher. This means that this trained person went to the child's home and elicited necessary information about the child's home background and past history. This type of study is often helpful in preventing failure. Sometimes by obtaining a reason for poor work a situation can be corrected, and th work will improve. Sometimes a better understanding with the home is the helpful thing. 
No teacher checked "outside tutoring". In many of the cases the intelligence level would make outside tutoring a fodlish procedure. In other cases the financial situation of the parent would make it inadvisable. However, there are probably a few cases within this group where the child would have benefited greatly by such outside coaching and the parent was able to pay for it. These would be children of at least average intelligence who were high in most subjects but low in one - for example, reading or arithmetic. Achievement in both of these subjects can improve greatly with skilled individual help.

Again there were no checks for "special tests and recommendations by the Bureau of Research". The records at the Bureau of Research show that this assertion is not correct. Some of these children were tested during the year 1941-42. Some of them had been tested by the Bureau earlier in their school lives and such records probably showed sufficient information to make further special testing unnecessary.

Bureau of Research findings. After careful search through various types of records at the Bureau of Research located in the Board of Education building it was discovered that 16 of these 66 children had had some type of special test given 
either at the Bureau or at the school they were attending at some time during their membership in the Louisville Public Schools. As before stated this testing was in addition to the periodic group tests given at stated intervals in these schools. Certain types of tests are given rather regularly in the first, fourth and sixth grades.

Such tests would be given after recommendation by the principal of the school the child was attending. The teacher might discover the need for the test but the suggestion would have to come from the principal's office. In some cases the psychologist from the Bureau of Research comes to the school to give individual or special group tests. In some cases the children go to the offices at the Board of Education.

Sometimes the principal of the school gives a group intelligence, general achievement or special subject test to an individual or special group. In these cases the results of such tests are recorded at the Board of Education and were consulted for this study.

Whenever a Binet test is to be given the visiting teacher makes a thorough investigation and vase study. Therefore, for every child who has been tested there is a rather complete tecord on file at the Board of Education. A carbon copy is, of course, also on file at the child's school where it is usually given to the teacher for perusal before it is filed. 
After a child has had such special tests recommendations are often made by the trained workers at the Bureau. Typical recommendations on these failures follow:

Case 1: Tested in 1B. Recommended temporary exclusion from school - low mental ability.

Case 2: Is to stay in $6 \mathrm{~A}$ as long as social adjustment is good. Not ready for Junior High. Cannot go on car to ungraded group.

Case 3: Tested in ungraded class, October of year 19411942. Coach class recommended.

Case 4: Tested April after failure in February in 6A. Recommended by Bureau of Research to be sent to Junior High School in September.

The staff at the Bureau of Research are prepared to consider other factors besides nental ability and academic achievement before making recommendations. They are, therefore, a valuable aid in preventing failure. As before stated it is unfortunate that there is not a larger staff so that more work of this sort could be done.

Information on available help in the Louisville school system. The Louisville school system ha certain types of help to offer children who are tentative failures. According to some authorities the help is inadequate. 
To begin with, the help offered at the Board of Education is centered for the most part in the Bureau of Research. The work is done under the sponsorship of a Director of this Bureau. A trained psychologist is available for individual testing and recommendation. Unfortunately she is unable to do all the work necessary in the Louisville schools since that is an impossibility for one person. Giving a complete Binet to one child requires an hour. This alone would be a full time job for one person.

All regularly issued testing material comes from this Bureau. The results of all group tests are sent back to the Bureau for consideration and recording.

Besides this aid, there is, for every group of schools in Louisville, a visiting teacher. This trained person is able to make contacts between the school and the home. She can often report back to the school facts which aid the teacher greatly in diagnosing the case. On the other hand she can carry to the home the recommendations of the school for further work. In writing up case records she puts on record what has been done for the child at an earlier time.

Within the school itself, as has been suggested, there might be coaching classes. At the time the Louisville Public School Survey was made there were only two such coaching

106

Works Survey, op.cit., p.291 
classes in Louisville. The Survey recommended that there should be many more if such things as the large number of pupils per teacher, and the short school day persist in our system.

In other schools a teacher of younger children who are dismissed early may do some coaching among the older children. occasionally attempts are made within a school to let a child work in a special subject with the group where he belongs academically. For example, a $5 \mathrm{~A}$ child who has reached his grade standard in everything else but needs special phonics help might join a 3B group in phonics. This, however, requires a skillful teacher and a well-adjusted child. The social adjustment is apt to be poor.

occasionally a principal finds time to help with remedial work. It is difficult, however, to add this to an already full schedule. The principal often has recommendations for special help before failure.

The classroom teacher is the one who is in a position to offer the most help. First, the child must be assured that only he can take over the job of preventing his failure in a subject or grade. This is the first and most important task of the teacher. This she can easily do in the classroom. Some individual assighments can be given there during school 
hours and other help may have to be given before or after the regular school day.

Then the work given the child must be so organized and so simplified that he can move easily from one step to the next doing the necessary work himself at home, before or after school hours. This should not be difficult for a well-trained teacher to do in such subjects as arithmetic and reading. Spelling may involve considerable individual work if the trouble is in understanding of phonics.

Such subjects as history, geography and science are much more difficult. However, they are usually closely connected with reading, and improvement in reading will often insure an improvement in these associated subjects.

Most of the teachers in Louisville have had a type of training which should enable them to offer this kind of help to failing children. There are a few specialists in reading difficulties. There should probably be many more.

However, the Louisville system seems to have available help for the prevention of failure if use is made of it. When failure as a motivating device becomes more unpopular with teachers and administrators perhaps help will be sought more often by the classroom teacher before the child actually fails. 


\section{CHAPTER VII}

THE CONSEQUENCES OF FAILURE 


\section{CHAPTER VII}

THE CONSEQUENCES OF FATLURE

The real results of failure could be so many and so caried it would be impossible to list or count them all. Pages have been written, for example, on the ineluence of failure on the child's mental attitude and on his relationships with his family and friends. Such results would require the skill of a trained oberver to note their presence or development.

However, for purposes of this study the results which could be observed by classroom teachers were chosen to be listed and more or less measured for this particular group of children. Some of these results were obtained by studying the answers to the questionnaire and others by obtaining figures from the two promotion sheets on which the child's name was likely to occur.

Questionnaire results. Item III on the questionnaire sent the teachers, whose promotion sheets showed failures in the 6A grade for the year 1941-42, asked the question, "Which of these did you notice the term after the child failed?" The items listed below occurred beneath the question. Side of each item is listed the number of tegchers checking that item. In all, 44 teachers checked one or more of these items. 
Teachers: Opinions As To Consequences of Failure of 6A Children For Year 1941-42
A. Child showed improvement in work 27
B. Showed no improvement in work 9
C. Gained in assurance 23
D. Became mature enough for group he entered 5
E. Acquired hostile attitude toward school and teacher 1
F. Became more of an attendance problem 9
G. Showed greater interest and effort 20
H. Showed less interest and effort 5
I. Improved in social behavior 3
J. Became more antagonistic to other children 2

This is, of course, based completely on teachers' judgment. The gain in improvement in work is substantiated by an improvement according to teachers' marks. This will be discussed fully later.

Gain in assurance shows a surprising number of checks considering the findings and opinions of psychologists and educators on the results of failure. Perhaps the child gained assurance in reading or spelling; but if in so doing he lost assurance in his associations with his fellows, he sudfered by the failure. 
As before stated a gain in maturity is such a subjectively judged item that little weight can be given to it in declaring failure of value to the child. If these children had gone on with their own groups it is probable that they would have eventually become as mature as the rest of their group who may have matured a bit ahead of them.

only one pupil was thought to have a hostile attitude towards the school and teacher while nine, according to the teacher, became more of an attendance problem. Exact figures on attendance will be given later.

Twenty, their teachers said, showed greater interest and effort the term after they were failed. It is possible that by skillful remedial work they could have as easily acquired this in the next grade and have had the benefits of new and different units of work for which their interest may have been much keener.

Five teachers said they showed less effort and interest. Three said the children improved in social behavior the next semester and two that they became more antagonictic to other children. The latter result seems the more natural one. There is certainly nothing inherent in failure which would make a child feel more kindly toward his follows.

These, then, were what the teachers considered were the results of failure. Other results could be measured more objectively. 
Teachers' marks. The teachers' marks would substantiate the statement that the work of the failures improved the semester after failing. Again it is to remembered that teachers' marks, particularly in the elementary school, are more or less subjective. The child's effort and his ability in comparison to the rest of the group may be important factors in deciding marks.

To measure improvement in work according to teachers' standards the average grades for the semester in which the child failed were set against his averages for the next semester. The number of subjects in which he had improved according to the teachers' marks were counted. The findings are shown in Table XXIII.

The subjects were all considered of equal value for this study. There might be argument that such subjects as art, music and handiwork were not academic subjects and therefore should not be included in this comparison.

It was impossible to check on this set of facts by objective test results. There are two sets of objective test results for most of these children, but infortunately they were given at the beginning of either semester and are therefore not a fair basis for judgment as to the value of failure from the standpoint of improvement in achievement.

It is true that some of the improvement might have been 


\section{TABIE XXIII}

Differences in Teachers' Grades Made by 6A Failures for Year 1941-42 in Which They Failed and the Following Semester

\begin{tabular}{cc}
$\begin{array}{c}\text { Number of Subjects } \\
\text { in which they improved }\end{array}$ & $\begin{array}{r}\text { Number of Children } \\
\text { improving }\end{array}$ \\
\hline 9 & 1 \\
8 & 3 \\
7 & 3 \\
6 & 1 \\
5 & 6 \\
4 & 4 \\
3 & 7 \\
2 & 7 \\
1 & 6 \\
0 & 4
\end{tabular}

Number of subjects in which marks aropped

1

2

2

1

3

0

4

1

Total number of children showing improvement 42

Total number of children showing no change

4

Total number of children showing worse marks

4 
due to better acquaintance with the subject matter and a greater understanding of the child's problems by the teacher. However, it is possible that the same improvement might have been made in the next grade if trial promotion studies are to be trusted.

Attendance persentages. On the questionnaire 9 teachers noted that children became more of an attendance problem. This fact was checked by comparing the percentage of attendance for the first semester with that for the second. It was found that by count 15 children were absent for a greater number of days the semester after they failed than during the one in which they failed. Four had exactly the same and 33 had a larger percentage of attendance. This was out of a group of 52 children. For the other 14 cases the record for the second semester was not complete either through moving from the district or some other similar cause. The percentages of increase and decrease of attendance are shown in Table XXIV. From this information it would certainly appear that attendance improved for this group as a whole the semester after the one in which they failed. This would not substantiate the belief that failure is apt to increase absence particularly absence beeause of truancy. However, in most

\footnotetext{
108

Buckingham, op.cit., pp.326-335. 109

Carleton M. Saunders, Promotion or Failure for the Elementary School Pupil, (New York: Teachers' College, Columbia Unibersity, 1941), p.33
} 


\section{TABLE XXIV}

Increase or Decrease in Percentage of

Attendance Shown by 6A Failures for Year 1941-42

in the Semester After the One in Which They Failed

\section{Percentages of Increase}

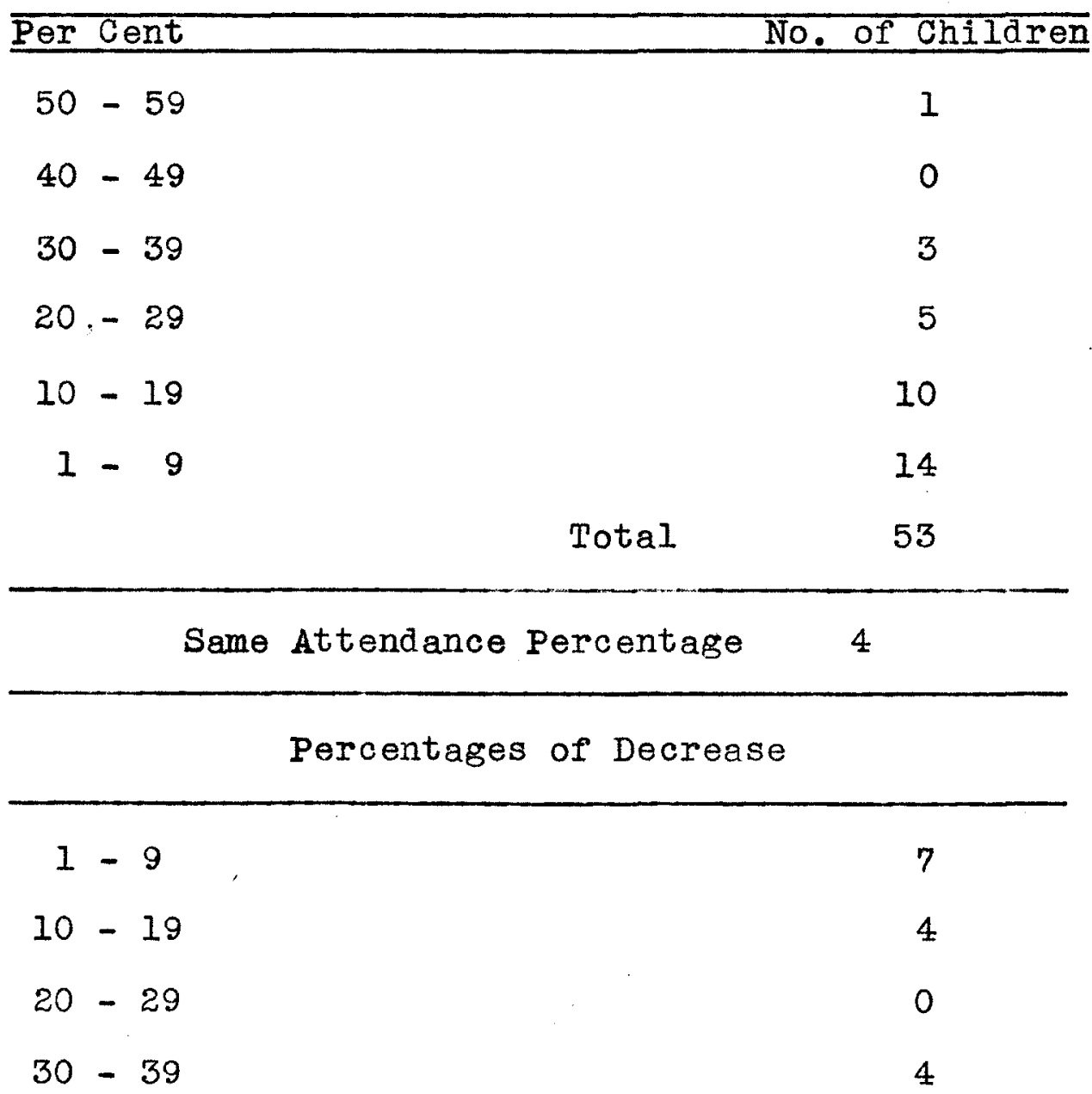

Total 15

Total Number of Children Recorded 52 
of these cases of increased attendance the child had been out because of illness the semester in which he failed. In one case, though, a child who had been absent through truancy showed a 20 per cent increase in attendance the term after the one in which he was not promoted.

According to the questionnaire findings many of the children listed as $6 \mathrm{~A}$ failures for the year $1941-42$ seem to have benefited by their failure according to teacher judgment. In some cases this judgment is substantiated by information from other sources.

Twenty-seven teachers felt that the work of the children had improved but a check of promotion sheets to compare marks for the two semesters show that actually 42 had improved in one or more subjects. Nine teachers said that the children they had recorded as failures made no improvement, a number which is close to the one revealed by a check of promotion sheets.

Only 9 recorded that children had become greater attendance problems and this fact, too, is borne out by actual count which shows that 33 gained in percentage of attendance. However, the factor of illness as a reason for absence in the semester in which the child failed should not be ignored. The other two results receiving the greatest number of check marks, gain in assurance and showing greater interest and 
effort, are not measurable except through their effect on achievement. They must be accepted as observations by the teachers, and therefore purely subjective. 
CHAPTER VIII

SUMMARY AND CONCLUSIONS 


\section{CHAPTER VIII}

\section{SUMMARY AND CONCLUSIONS}

This study, then, has attempted to show the points of view about failure now held by the educators throughout the country, statistics as to the amount and the variation in the amount of failure, the reasons and the consequences usually accompanying failure and the methods advocated and applied for failure prevention.

It has, further, presented the facts about one group of failures in the Louisville Public Schools, the children who $f$ ailed in the $6 \mathrm{~A}$ grades during the year 1941-42. From these facts certain conclusions were drawn and suggestions made for the reduction of the number of failures in the Louisville Public schools.

The Louisville Public School survery found a retardation of 43.61 per cent of the children in the $6 \mathrm{~A}$ grade with a mean retardation of 1.63 years. The surveyors found between five hundred and six hundred pupils in the elementary schools who were fourteen years old or older. This is a situation which would not obtain without a high percentage of non-promotion. Educators throughout the country have found

\section{9 \\ Public School Survey, p.258.}


these same facts although in many places recently the amount of retardation has decreased materially.

The annual reports of the superintendents of schools for five years were also consulted. It was found that the $6 \mathrm{~A}$ had the lowest rate of failure of any of the elementary grades. For the five years studied the rate was 2.59 per cent for the $6 \mathrm{~A}$ in contrast to 17.48 per cent for the $1 B$, the grade with the highest rate of non-promotion. The literature shows that this variation is generally true in the schools of our nation.

To get the data concerning the $6 \mathrm{~A}$ failures promotion sheets for February and June of the school year 1941-42 were used. It was found there were thirty-three children failing in the February semester and thirty-three in June. Two children failed both semesters and their names therefore appeared twice.

The group of failures ranged in age from eleven years eight months to sixteen years five months with a median age of twelve years eleven months. In grouping according to the year of age the largest block came within the twelve year limit. According to the Kuhlmank-Anderson group intelitigence tests the largest number of children fell within the serentyfive to ninety, or dull-normal group with some few testing above one hundred and a few below the seventy-five level. 
On this test 43.1 per cent tested normal or above.

Some of the studies quoted show that this dull-normal group of children are the ones who continually make up the largest percentage of failures particularly where the children below $75 \mathrm{I} . \mathrm{Q}$. are cared for in special classes. The very low child is also apt to be passed on because he is judged completely incapable.

Seventeen of the 64 children, or 26.6 per cent, had special tests at some time during their school lives according to Bureau of Research records. Some of these were given the Binet individual intelligence test by a psychologist from the Bureau and some were given a group test by such a worker, or teacher or a principal at some time besides the time when a regular test was given his entire group.

Questionnaires were sent to all teachers who had $6 \mathrm{~A}$ failures listed in their promotion sheets for that year. Answers were received from all but four teachers giving questionnaire information for fifty-nine of the sixty-six cases.

The teachers were asked to check what they considered the causes of failure. The most of them checked poor attendance. The attendance percentages of this group showed a wide range. Three were present 100 per cent of the time while seventy were absent more than 50 per cent of the time with the others ranging in between. Attendance was also given as a chief cause 
of failure in many of the lists sent in by teachers or administrators to the rriters quoted in the literature section of this study.

The chief reasons checked were illness, such other reasons as accident, indifference, help at home, work, truancy, and lack of clothing in the order named.

Next in order as a reason given for failure was mental incapacity. This also, bears out the findings of other educators. However by group tests only six were actually proven mentally deficient with twenty-seven in the dull-normal group. According to the questionnaire twenty of the teachers used the group test results as a basis for their decision that the failures were mentally incapable of doing the work. Ten used individual test results and fourteen admitted that in their own judgment the children were mentally incapable.

The twenty-five children who were judged mentally incapable by thir teachers were next studied. It was found that according to group tests the twenty-five who had been given such tests were divided in this way - three actually below seventy-five, eighteen from 75 to 90 and four abore 90 .

Poor home conditions came next as a factor in failure, than lack of interest and effort, a point which was not strange when eight of this group were over fourteen and three almost 
fourteen. Unwise previous promotion was the next in order as a reason for failure. These reasons appeared on various lists too, in the literature but were questioned often as legitimate causes of failure.

Thirteen teachers checked misbehavior as a cause for failure with inattention as the commonest cause, anti-social behavior next and insubordination in one case. Late entrance came next with three having entered from rural schools, three from other city schools, three from Louisville parochial schools and three from public schools in Louisville.

Eleven checked immaturity although no child was below the normal age for the grade and there was one child thirteen and one fourteen. Poor health came next as a cause of nonpromotion with physical defects, frequent transfer and such other reasons as daydreaming and poor preparation completing the list. All these reasons were constantly repeated where research was done on the subject in other places.

Teachers' marks on the promotion sheets were used to see if the children had been given failing marks in their school subjects. In the large majority of cases they had but there were an appreciable number who were marked average in their work and one who was above average.

The achievement test results showed only two children whose average achievement was $6 \mathrm{~A}$ or above byt many children 
who had high achievement in certain subjects which in the elementary school usually demonstrates the ability to do well in all with special remedial instruction. Many authors advocated individual remedial instruction as a remedy for failure.

In comparing the achievement of these children with others in their own groups it was found that they ranged from the bottom to the top. Two had from 90 to 100 per cent of their classes below them in achievement.

In comparing teachers' grades and achievement test results it was found that in some cases a child who was achieving at sixth grade level was marked below average which of course was possible if he were in a good group. This group of failures were found for the most part to rate below average for thei grade both in teachers' grades and achievement results.

When asked what help was given before failure most teachers checked that they had given help. Thirteen children were in coach classes and ten had case studies made by the visiting teachers. According to records available at the Bureau of Research sixteen had had some special test during the time of their membership in our system.

Twenty-seven felt that the children had improved in academic work the term after they failed. This was substantiated by the marks noted on the promotion sheets which showed 
forty-two children showing improvement and only four getting worse marks the second semester. This is not bourne out by experimental research in many places. Trial promotion schemes have been one type of experiment.

Most of the teachers of this group were convinced that they had gained in assurance, in interest and effort, and had become more mature while only a few found children showing no improvement in work, becoming more of an attendance problem and showing less interest and effort. Here again we find most of the writers quoted in the literature section disagreeing with these Louisville teachers.

The percentages of attendance derived from figures on the promotion sheet showed that by actual count, thirty-three chilaren improved in attendance the term after they failed while fifteen were absant a greater number of days the second semester than the first.

. This fact may be partly because illness was the cause of much of the absence in these cases, and, therefore, with improved health during the second semester attendance naturally improved. A great number of the writers whose work is mentioned in this study would disagree with these findings.

\section{Conclusions.}

1. If retardation in our elementary schools is great there are still too many failures. 
2. The number of overage children demonstrates a situation which is deporable since no elementary school is prepared to handle adolescents. This study found this situation mentioned in the survey to be true in the $6 \mathrm{~A}$ grade in the year studied.

3. There is no good reason why the $6 \mathrm{~A}$ should have a lower rate of failure than other grades. Reasons which obtain for one should obtain for all.

4. More use should have been made of the test material and services of the Bureau of Research before these children became failures. Teachers' judgments are not reliable to the mental capacities of children.

5. Poor attendance would probably lose first place as a cause for failure if adequate makeup work were given absentees. The teacher should give the same attention to the absentee's work that she does to that of the child who is present in her classroom. If she sends to his home or gives to him upon his return detailed and carefully organized assignments he should be able to make up at least part of the work he has missed. 6. Inattention and lack of interest and effort as causes for failure reflect as much on the teacher as on the child. Disagreement between teachers' grades and achievement test levels in specific subjects may be due to one of these causes.

7. Late entrance in itsele is not a justifiable cause 
for failure. A slightly different course of study in the sending school should not penalize the child when he enters the receiving school.

8. In a few cases teachers failed children whom they themselves had marked average or above. This procedure is hard to und erstand.

9. The achievement tests showed that some of these children had high achievement in certain subjects. It is probable that with expert remedial instruction in the subjects in which their achievement was low they could have gone on with their group.

10. These children were not all at the bottom of their groups in achievement. Unless all those below them failed it is questionable if they should have done so.

11. If academic achievements based on definite grade standards is the only criterion for promotion these children were doomed to failure for only two tested $6 \mathrm{~A}$ or above.

12. If specific teacher help had been given before failure this group of children would have been smaller. . It is probable that the help was not of a remedial type.

13. More coach classes should be established or some one in each school made responsible for the children who would benefit by specific remedial instruction. This should not, however, free the classroom teacher from offering help daily to these children. Within each classroom practically every 
subjeat should be organized in flexible and everchanging groups. A child should move from one to another of these groups as his knowledgea and skills increase. He should himself be conscious of his growth and mastery as evinced by his ability to pass from one group to another.

14. If these children showed greater interest and effort the semester after they failed it is probable that a similar result might have been obtained the prededing term by other methods.

15. It is regrettable that sixty-four children were denied the privilege of entering junior high with their groups. The junior high is set up to take care of this age group and should be prepared to offer any necessary remedial work. The reasons given for the failure of these children did not seem valid in all cases, and the help given before failure appeared inadequate. The improvement in achievement for the semester after failing as demonstrated by teachers' marks may well have been colored by the teachers' desire to prove to herself that she was right in advocating failure. The evidence seems unconvincing. 
BIBLIOGRAPHY 


\section{BIBLIOGRAPHY}

\section{A. Books}

Ayres, Leonard P., Laggards in Our Schools. Philadelphia: William F. Feil Company, I909. $236 \mathrm{pp}$.

Brueckner, Leo J., The Changing Elementary School. New York: Juor Publishing Company, 1932.

Brueckmer, Leo J., and Ernest 0. Melby, Diagnostic and Remedial Teaching. New York: Houghton-Mifflin Company, $1931, \overline{598} \mathrm{pp}$.

Buckingham, Burdette R., Research for Teachers. New York: Silver-Burdett and Company, 1926, $380 \mathrm{pp}$.

Caswell, Hollish, Non-Promotion in Elementary Schools. Nashrille: Peabody College, 1933, $100 \mathrm{pp}$.

Cubberly, Ellwood P., The Principal and His School. Boston: Houghton-Mifflin Company, 1923, 571 pp.

Featherstone, W.B., Teaching the Slow Learner. New York: Teachers' College, Columbia University, 194I, $100 \mathrm{pp}$.

Freeman, Frank S., Individual Differences. New York: Henry Holt and Company, ig $34,355 \mathrm{pp}$.

Garrison, Karl C., Psychology of Exceptional Children. New York: Ronald Press Company, 1940,351 pp.

Heck, Arch 0., Administration of Pupil Personnel. Boston: Ginnard Company, 1929, 470 pp.

Ingram, Christine P., Education of the Slow-Learning Child. Yonkers-on-Hudson, New York: World Book Company, $\frac{1935,419}{\mathrm{pp}}$.

Jordan, Arthur M., Educational Psychology. New York: Holt and Company, 1934, 522 pp.

Mort, Paul R., Individual Pupil. New York: American Book Company, $1928,383 \mathrm{pp}$.

Otto, Henry J., Elementary School Organization and Administration. New York: D. Appleton-century Company, 1934, $652 \mathrm{pp}$. 
otto, Henry J., Promotion Policies and Practice in Elementary Schools. Minneapolis; Educational Test Bureau, Inc. 1935, 171

Reeder, Ward G., Fundamentals of Public School Administration. New York: Macmillan Company, 1941, $798 \mathrm{pp}$.

Riulin, H. N., Educating for Adjustment. New York: D. AppletonCentury Company, $1936,419 \mathrm{pp}$.

Saunders, Carleton M., Promotion or Failure For the Elementary School Pupil. New York: Teachers College, Columbia University, 1941, $87 \mathrm{pp}$.

Strayer, George D., and N.L. Engelhardt, The Classroom Teacher. New York: American Book Company, 1920, 400 pp.

Terman, Lewis M. , Intelligence of School Children. Boston: Houghton-Mifflin Company, $1919,313 \mathrm{p}$.

Washburne, Carleton, Adjusting the School to the Child. Yonkerson-Hudson, New York: World Book Company, $\overline{1932,189}$ pp.

\section{B. Periodical Articles}

Adams, W.S., "Why Teachers Say They Fail Pupils", Educational Administration and Supervision, 18:594-600. November, 1932.

Asfahl, W.D., "A Board of Education Considers Retardation and Promotion", American School Board Journal, 102:30-31, May, 1941.

Barker, Roger G., "Success and Failure in the Classroom", Progressive Education, 19:221-24, April, 1942.

Beals, Frank L., "Educating the Slow Child", Hygeia, 20:876-7, 956, November, December, 1942.

Bell, John, "Failure Prevention", Clearing House, 15:134-37, November, 1940.

Borgeson, F.C., "Causes of Failure and Poor School Work Given by Pupils", Educational Administration and Supervision, 16:542-48, october, 1930 . 
Boyer, Philip A., "School Progress", Review of Educational Research, 9:168-71, April, 1939.

Buckingham, B.R., "An Experiment in Promotion", Journal of Educational Research, 3:326-35, May, 1921.

Bucklen, Harry E., "Should Johnnie Be Promoted", Journal of Education, 125:144-45, May, 1942.

Coates, Mary Weld, "Democracy and Student Failures", School and Society, 52:398-400, 0ctober, 1940.

Cook, Walter W., "Some Effects of the Maintenance of High Standards of Promotion," Plementary School Journal, 41:430-37, February, 1941 .

Cornell, Ethel L., "Why Are More Boys Than Girls Retarded in School", Elementary School Journal, 29:96-106,

Cowen, Philip A., "Special Classes vs. Grade Groups for Subnormal Pupils", School and Society, 48:27-28, July 2, 1938.

Cutts, Norma E., "The Mentally Handicapped", Review of Educational Research, 11:261-76, June, 1941.

Deming, Leon J., "An Appraisal of Certain Procedures in the Classification and Promotion of Pupils", National Elementary Principal, 19:621-25, July, 1940.

Ellsbree, Willard S., "School Practice That Help and Hurt Personally", Childhood Education, 18:197-204.

Fmery, James Newell, "When Johnny Doesn't Pass", Journal of Education, 125:86-87, March, 1942.

Bmery, James Newell, "That Opportunity Group", American School Board Journal, 96:43, June 1938.

Flaum, Larry, "Social View of Student Failures", Journal of Education, 126:12-13, January, 1943.

Gordon, Hans G., "Promotions", Review of Educational Research, 12:26-31, Bebruary, 1942.

Greene, H. A., and G. Freden, "Failures and Double Promotions in the Elementary School", Journal of Educational Research, 17:262-72, April, 1928. 
Guilford, Charles C., "Why Pupils Fail", Educational Method, 12:219-22, January, 1933.

Haggerty, M. E., "Incidence of Undesirable Behavior in Public School Children", Journal of Educational Research, 12: 102-22, September, 1925.

Hawley, W.E., and L.A. Peckstein, "Diminishing Returns in NonPromotion", Elementary School Journal, 22:584-96, April,1922.

Hayes, Eleanor H., "Why Pupils Fail", Educational Method, 13:25-28, October, 1933.

Hildreth, Gertrude, "Educational Provisions for the Slow Learning Pupil", Educational Administration and Supervision, 25:491-512, 0ctober, 1939.

Hooker, Grover C., "Did the Pupils Fail?" Educational Method, 12:367-68, March, 1933.

Jahr, Herman M., "The Backward Child", Hygeia, 20:636-39, August, 1942.

Knudson, K.O., "Program for Elimination of Failures in Elementary Schools", Elementary School Journal, 38:729-30, June, 1938.

Lafferty, H.M., "A Study of the Reasons for Pupil Failure in School", Educational Administration and Supervision, 24:360-67, May, 1938.

Lee, John L., "Special Schools and Classes", Review of Educational Research, 9:180-84, April, 1939.

Levy, Muriel M., "What Price Failure", School and Society, $47: 766-68$, June 11, 1938.

McGinnis, William G., "Dodging the Blame for Failures", Journal of Education, 117:209-11, April 16, 1934.

Mones, Leon, "A Cleveland Junior High Develops Courses for Binet, (how I.Q.) Pupils", Clearing House, 14:451-57, April, 1940.

Miller, Joseph, "Causes of Success and Failure in School", Educational Method, 10:327-33, March, 1931. 
Mulligan, L.H., "The Responsibility of Parents in Raising A Mentally Deficient Child", Kentucky School Journal, 20:180-20, December, 1941 .

Myers, Fannie, "We Experiment With a Non-Failure Program", Childhood Education, 18:205-09, January, 1942.

Otto, Henry J., "Pupil Failure as an Administrative Device", Elementary School Journal, 34:576-89, April, 1934.

Phifer, Juliette Virginia, "Steps Toward a Better School Life for Retarded Pupils", School and Society, 56:387-88, October, 1942 .

Pigsley, C.A., "Reducing and Handling Student Failures", American School Board Journal, 86:18-20, March, 1933.

Reinoehl, C.M., "Promotional Units Eliminate Grade Failures", Nation's Schools, 26:70-72, October, 1940.

Sampson, W.H., and F.T.Bertsche, "Failures Cut to one Per Cent", Journal of Education, 124:238-39, October, 1941.

Schmidt, Bernamine G., "Current Administrative Practices in Educational Provision for the Rientally Retarded", Educational Administration and Supervision, 28:541-45, october, 1942

Stenguist, John L., "How Baltimore Handles Pupil Promotions", Nation's Schools, 27:41-44, January, 1941.

St.John, Charles W., Maladjustment of Boys in Certain Elementary Grades", Educational Administration and Supervision, 18:659-72, December, 1932.

Theman, Viola, "Continuous Progress in School", Childhood Edudation, 18:21-23, September, 1941.

Worth, C. L., "A Better Basis for Promotion", American School Board Journal, 100:55, April, 1940. 


\section{Publications of Learned Organizations}

Briggs, E. E. , and Committee, "Studies of Failures in the Sioux City Public Schools", Eighth Yearbook of the Department of Elementary School Principals of the $\mathrm{N}_{\mathrm{a}}$ tional Education Association, Washington: National Educational Association, April 1, 1929. pp. 240-244.

Foster, Emery M. and Eíse H. Martens, "Statistics of Special Schools and Classes for Exceptional Children", Biennial Survey of Education in the United States (1934-36) Washington: United States Printing office, 1938.

Hartwell, Charles S., "Grading and Promotion of Pupils", National Education Association Addresses and Proceedings Washington:National Education Association, I910. pp.294-300.

Judd, C.H., "Measuring the Work of the Public Schools", Education Survey of Cleveland, Ohio:Cleveland Foundation. pp.17-43.

Kuznets, G.M., and Olga McNemar, "Sex Differences in Intelligence Test Scores", Thirty-ninth Yearbook of the National Society for the study of Education, Part II,Bloomington, Illinois:Public School Publishing Company, 1940. pp.211-17.

Report and Recommendations of the Joint Committee on Maladjustment and Delinquency of the Board of Education of New York

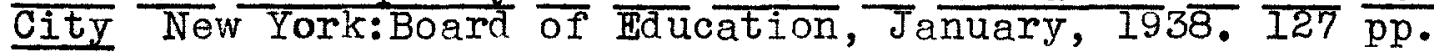

Washburne, Carleton W., "Adapting the Schools to Individual Differences", Twenty-fourth Yearbook of the National Society for the study of Education, part II. Bloomington, IlIinois: Public school Publishing Company, 1925, pp.1-132.

Wegleiss, David E., Hobart Corning, G.D.Taylor and Herbert $\mathrm{B}$. Weet, "Promotion Problems from Kindergarten Through Graduate School", Ninth Yearbook of the Department of Superintendents of the National Eacation Association Washington: February, $\overline{19} 3 \overline{1,} \mathrm{pp} .17-149$.

Whipple, Guy M., "Grouping of Pupils", Thirty-fifth Yearbook of the National Society for the study of Education, Part I, Bloomington, IIIinois:Public School Publishing Company, 1936 , pp.135-600. 
Works, George A., Louisville Public School Survey, A Report on the Public Schools of Louisville, Kentucky Louisville:

City of Louisville, I943. pp.257-60.

$$
\text { D. Encyclopedia Article }
$$

Sumption, M.R., "School Progress", Encyclopedia of Educational Research, 1941 edition, 1054-57. 